\title{
CONTEMPORARY PROBLEMS OF NUMERICAL MODELLING OF UNIQUE STRUCTURES AND BUILDINGS
}

\author{
Alexander M. Belostotsky ${ }^{1,2,3,4}$, Pavel A. Akimov ${ }^{1,2,4,5}$, Irina N. Afanasyeva ${ }^{1,2}$, \\ Taymuraz B. Kaytukov ${ }^{2,5}$ \\ ${ }^{1}$ Scientific Research Center "StaDyO", Moscow, RUSSIA \\ ${ }^{2}$ National Research Moscow State University of Civil Engineering, Moscow, RUSSIA \\ ${ }^{3}$ Perm National Research Polytechnic University, Perm, RUSSIA \\ ${ }^{4}$ Research Institute of Building Physics of Russian Academy \\ of Architecture and Construction Sciences, Moscow, RUSSIA \\ ${ }^{5}$ Russian Academy of Architecture and Construction Sciences, Moscow, RUSSIA
}

\begin{abstract}
The distinctive paper is devoted to contemporary problems of numerical modelling of unique structures, buildings and facilities and corresponding directions of activity of Scientific Research Center "StaDyO" including development, verification and use of corresponding software, development and refinement of methods of structural analysis, solution of scientific and technical problems, scientific and educational activity. Experience in theoretical and practical computational analysis is under consideration as well (26-year history).
\end{abstract}

Keywords: numerical modelling, computational analysis, structural analysis, structures, buildings, software

\section{АКТУАЛЬНЫЕ ПРОБЛЕМЫ ЧИСЛЕННОГО МОДЕЛИРОВАНИЯ СОСТОЯНИЯ ЗДАНИЙ, СООРУЖЕНИЙ И КОМПЛЕКСОВ}

\author{
А.М. Белостоцкий ${ }^{1,2,3,4}$, П.А. Акимов ${ }^{1,2,4,5}$, И.Н. Афанасьева ${ }^{1,2}$, \\ T.Б. Кайтуков ${ }^{2,5}$ \\ ${ }^{1}$ ЗАО «Научно-исследовательский центр «СтаДиО», г. Москва, РОССИЯ \\ ${ }^{2}$ Национальный исследовательский Московский государственный строительный университет, \\ г. Москва, РОССИЯ \\ ${ }^{3}$ Пермский национальный исследовательский политехнический университет, г. Пермь, РОССИЯ \\ ${ }^{4}$ Научно-исследовательский институт строительной физики Российской академии \\ архитектуры и строительных наук, г. Москва, РОССИЯ \\ ${ }^{5}$ Российская академия архитектуры и строительных наук, г. Москва, РОССИЯ
}

\begin{abstract}
Аннотация: В настоящей статье рассматриваются актуальные проблемы численного моделирования состояния зданий, сооружений и комплексов, а также соответствующие направления деятельности ЗАО «Научно-исследовательский центр СтаДиО» (НИЦ СтаДиО), включая вопросы разработки, верификации и апробации соответствующего программного обеспечения, реализации образовательных проектов, а также исследования и развития численных и численно-аналитических методов решения актуальных научно-технических задач. Кроме того, приводятся краткие сведения о 26-летнем опыте коллектива НИЦ СтаДиО в области расчетно-теоретических исследований пространственного температурного и напряженно-деформированного состояния, устойчивости, прочности и надежности трубопроводов, технологического, электротехнического и подъемно-транспортного оборудования, машин и механизмов, систем «оборудование - трубопроводы», строительных конструкций, систем «основание - наземное сооружение» и «основание - подземное сооружение» особо ответственных объектов при учете нормативно регламентированных и фактических сочетаний температурных, статических, ветровых, эксплуатационных (вибрации) и особых динамических (сейсмических, ударно-волновых, аварийных и других) воздействий.
\end{abstract}

Ключевые слова: численное моделирование, комплексы программ, здания и сооружения 


\section{INTRODUCTION}

International and Russian experience, reflected in the numerous papers and monographs, wellknown events in the recent years in various cities all over the world indicate that problem of technological safety of metropolis is rather actual, science-intensive and, unfortunately, still far from practical solution. An effective and economically justified solution of these problems is normally based on predictive mathematical modeling of state (static and dynamic stress-strain state, gas- and hydrodynamic state, thermal state, etc.) of structures, buildings and facilities with the use of corresponding universal and specialized software systems, realizing numerical methods of mechanics (fluid mechanics, gas dynamics, solid mechanics, structural mechanics) [11,12, 18-22,24-26]. In accordance with the state-of-the-art concept mathematical models must accompany objects at all stages of their life cycle (design and construction, operation, repair and reconstruction), providing an adequate and complete analysis and forecast of the state as part of computer-based structural health monitoring systems [13]. Scientific Research Center "StaDyO" (SRC "StaDyO") was founded in Moscow in 1991 as one of the Russian pioneers offering and performing computer-oriented computation services for industrial purposes. Problems dealing with effects of static, temperature and dynamic loads on complex buildings, equipment and pipelines of nuclear and hydro power plants, wind structures, offshore structures etc. are under consideration. SRC "StaDyO" develops and distributes computer-aided design systems as well as the respective specialized software. Besides, SRC "StaDyO" distributes technical software in the area of structural mechanics and other related areas. During twenty six years SRC "StaDyO" worked in the field of design and numerical analysis of structures, equipment and pipe systems of nuclear power plants, hydro power stations and dam constructions, offshore structures and other complicated systems.

\section{DIRECTIONS OF ACTIVITY OF SCIENTIFIC RESEARCH CENTER "STADYO"}

\subsection{Contemporary problems of mathemati- cal modelling of unique structures, buildings and facilities.}

Directions of activity of SRC "StaDyO" include the following contemporary problems of mathematical modelling of unique structures, buildings and facilities:

- modelling of interaction of buildings and structures with a foundation with allowance for real properties, stage-by-stage construction and actual operation history;

- structural analysis with allowance for physical, geometrical and other nonlinearities (plasticity of metal, creep and crack formation of reinforced concrete, nonlinear rheology of the foundation, large displacements, loss of stability, postbuckling behaviour, contact problems (friction separation, etc.)) [1517];

- structural analysis with allowance for structural and technological specificity (structural (constructive) nonlinearity, genetic nonlinearity) of buildings and facilities (construction sequence, stage-by-stage construction, sensitivity of buildings and structures, assessment of the quality of the constructive solution from the position of the sensitivity of the stress-strain state to corresponding design deviations) [15-17];

- numerical modelling of wind flows and loads (average and pulsation components, loads on facade structures, pedestrian comfort, vortex resonance oscillations), experimental validations of wind load analysis;

- seismic analysis (with allowance for acceleration spectra (versions of the linear-spectral theory), accelerograms, platform models, wave effects) [14];

- progressive collapse analysis of buildings and facilities with allowance for real dynamic highly nonlinear effects of elastoviscoplasticity and large displacements; 


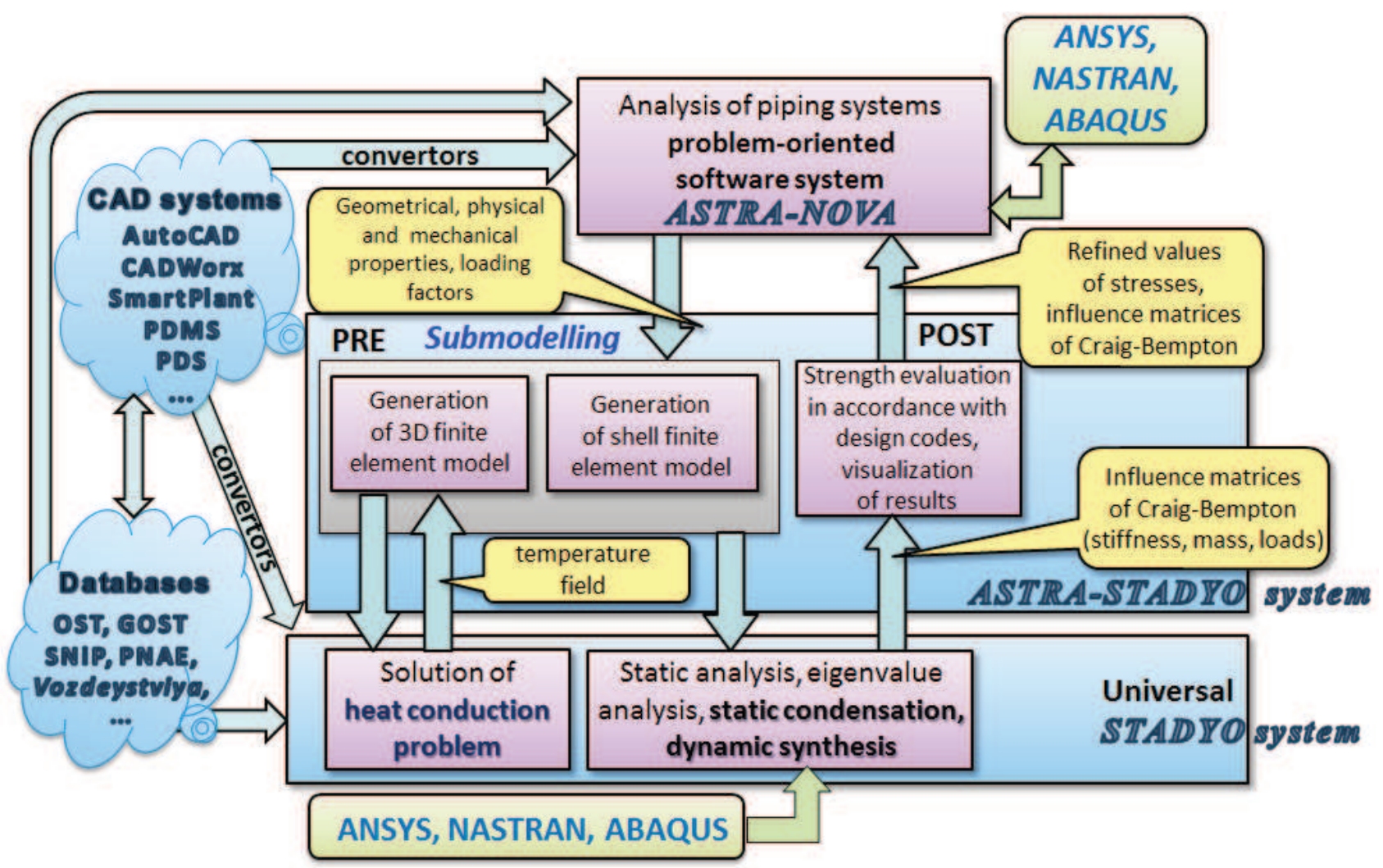

Figure 1. Proprietary software systems based on superelement method (substructuring method):universal (STADYO) and object-oriented (ASTRA-NOVA).

- development and refinement of methods and algorithms for solution of large-scale computational problems (direct and iterative solvers, superelement technology, adaptive schemes, parallelizing, etc.);

- development of calibratable mathematical and computer models as part of structural health monitoring systems at the stages of erection and operation of buildings and facilities;

- application of algorithms of aerodynamics for modelling of snow sedimentations, explosion loads and distribution of hazardous emissions;

- numerical modelling of three-dimensional non-stationary problems of fire resistance;

- solution of coupled problems of aerohydroelasticity.

\subsection{Development and verification of software.} During twenty six years specialists from SRC "StaDyO" successfully worked in the field of design, development and verification of proprietary software systems (Figure 1). STADYO is the universal software system providing temperature fields, static, stability and dynamic analysis (including response spectra and accelerations definition) as well as fracture mechanics and strength analysis and optimization of arbitrary combined 2-D and 3-D solid, shell, plate and beam mechanical systems by the finite elements, superelement and other modern numerical methods. STADYO is verified and certificated in Gosatomnadzor RF (State Nuclear Safety Commission of the Russian Federation), it is applied in the leading design and research institutes and plants (for instance, Atomenergoproject (Russia), Hydroporoject (Russia), Teploenergoproject (Russia), Energoproject (Bulgaria), Siemens AG (Germany), etc.)). ASTRA-NOVA is the software system for nuclear power plants, fuel power plants, which provides petroleum pipelines stress-strain analysis in accordance with existing Russian and international design codes (Figure 3). 

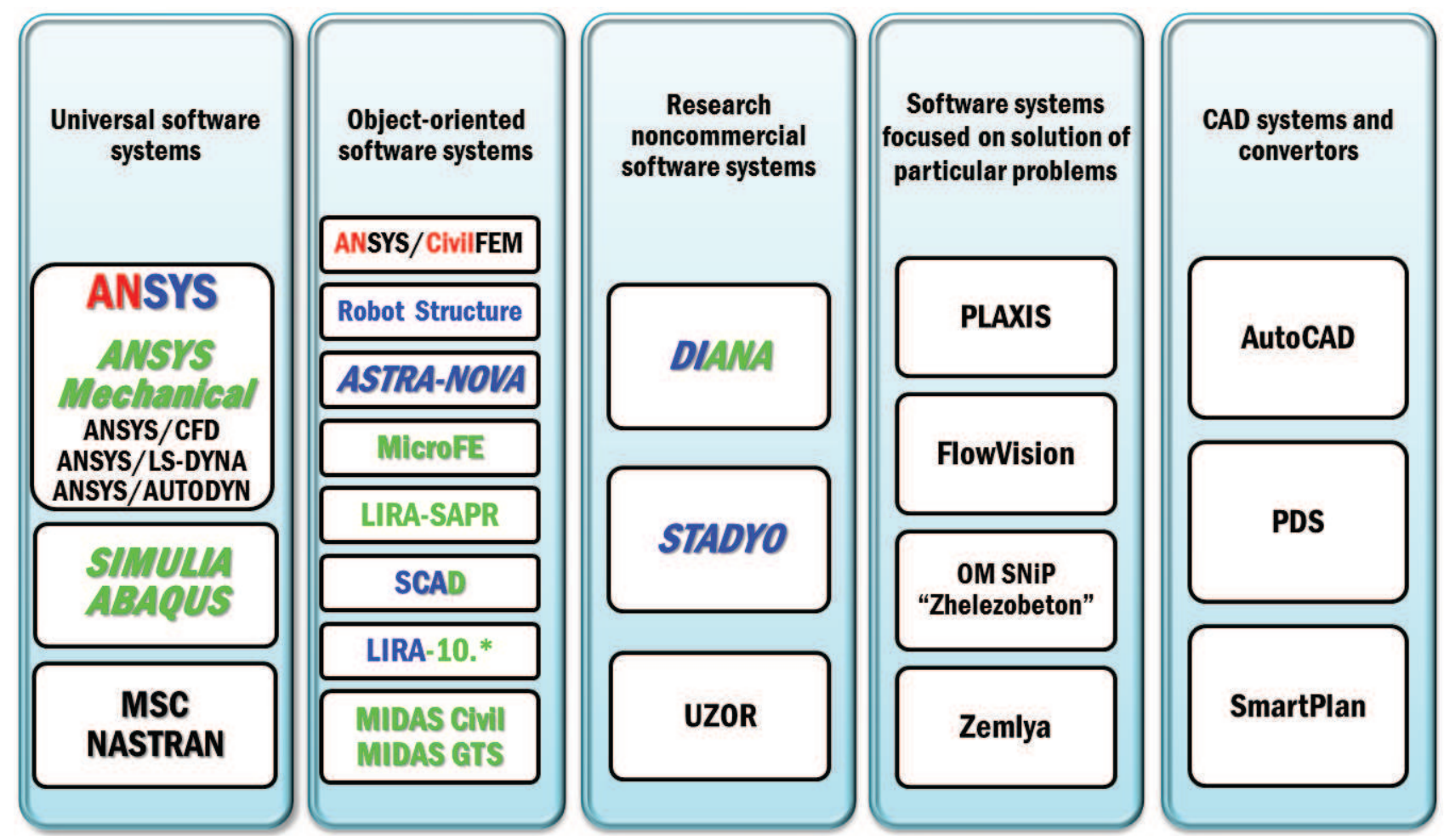

Figure 2. Software systems for analysis of loads and effects, strength and stability of structures, buildings and facilities.

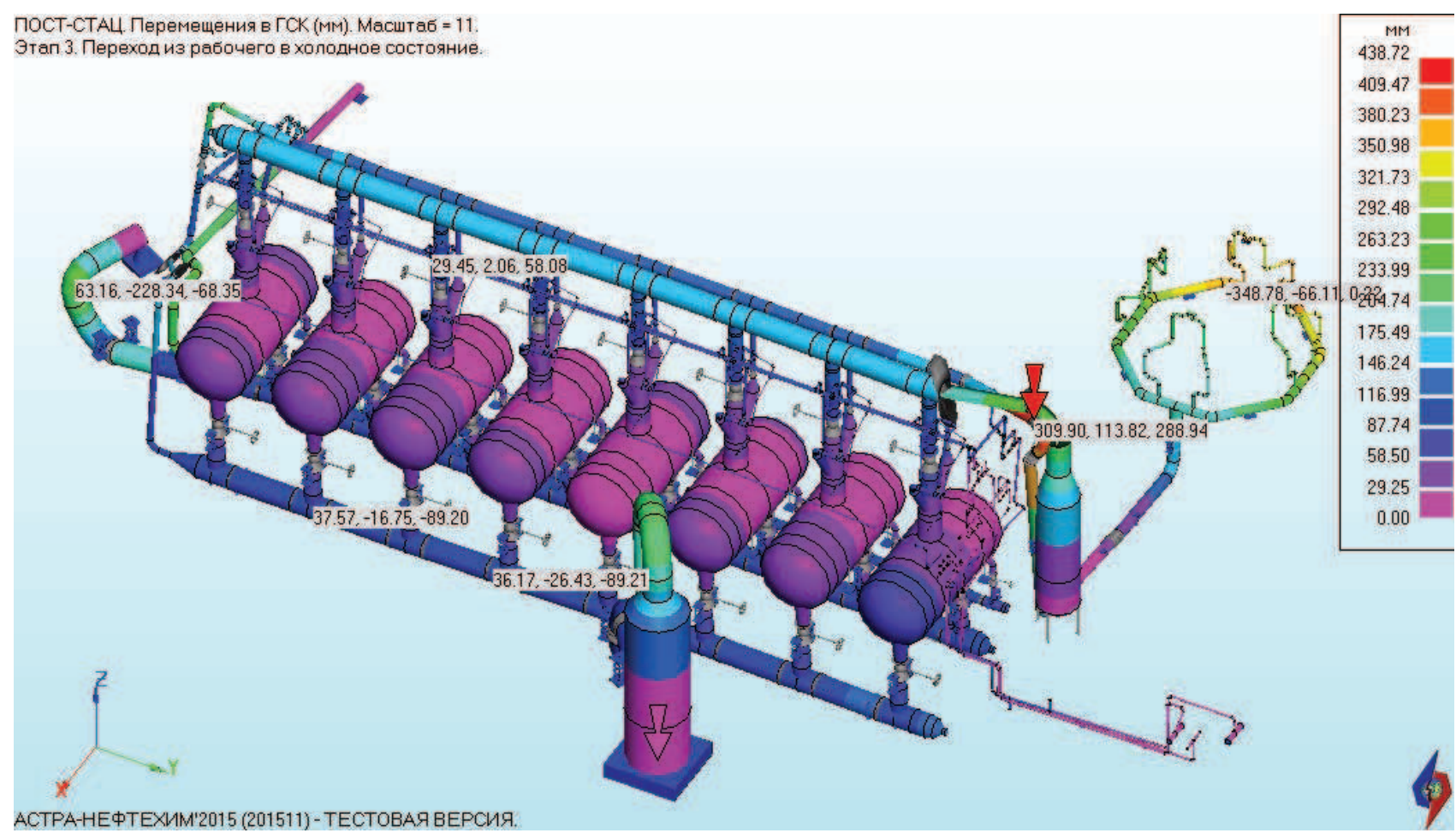

Figure 3. Modeling of complex supporting structures and equipment in the ASTRA-NOVA software system (sample). 
SyMonEx is informational \& diagnostic computer system of monitoring and expert safety evaluation of complicated power energetic structures. These software systems have powerful pre- and postprocessors, which allow to prepare input data and analyse results, correspond to world standards and can work together with various modern $\mathrm{CAD} / \mathrm{CAM}$ systems and data bases. Besides, it is vital to specify the following activities:

- review of results of structural analysis with the use of verified software;

- training of specialists-users of software systems which provide mathematical modelling of structures, buildings and facilities;

- qualification tests and certification of specialists dealing with computational structural analysis and corresponding experts reports;

- verification of numerical methods and software used in design and structural analysis;

- construction and technical expertise of buildings and facilities (including cases of local destruction).

\subsection{Development and refinement of methods of structural analysis.}

Research and development of numerical (finite element method, boundary element method, variation-difference method, meshless method, finite volume method etc.) and semianalytical (discrete-continual) methods of structural analysis [1-10,23] are the most important aspects of ensuring safety of structures and buildings.

Particularly the field of application of discretecontinual methods (discrete-continual finite element method, discrete-continual boundary element method, discrete-continual variationdifference method), which are now becoming available for computer realization, comprises structures with regular (in particular, constant or piecewise constant) physical and geometrical parameters in some dimension (so-called "basic" direction (dimension)). Considering problems remain continual along "basic" direction while along other directions discretecontinual methods presuppose corresponding mesh approximation.
Analytical solution along basic direction is apparently preferable in all aspects for qualitative analysis of calculation data. It allows investigator to consider boundary effects when some components of solution are rapidly varying functions. Due to the abrupt decrease inside of mesh elements in many cases their rate of change can't be adequately considered by conventional numerical methods while analytics enables study. Another feature of discretecontinual methods is the absence of limitations on lengths of structures. Hence it appears that in this context discrete-continual methods are peculiarly relevant.

Solution of corresponding resultant systems of equations with immense number of unknowns is the most time-consuming stage of the computing, especially if we take into account the limitation in performance of personal computers, contemporary software and necessity to obtain correct solution in a reasonable time. However, high-accuracy solution at all points of the model is not required normally, it is necessary to find only the most accurate solution in some preknown domains. Generally the choice of these domains is a priori data with respect to the structure being modeled. Designers usually choose domains with the so-called edge effect (with the risk of significant stresses that could potentially lead to the destruction of structures, etc.) and regions which are subject to specific operational requirements. It is obvious that the stress-strain state in such domains is of paramount importance. Specified factors along with the obvious needs of the designer or researcher to reduce computational costs by application of sophisticated correct discrete and discretecontinual methods cause considerable urgency of constructing of special algorithms for obtaining local solutions (in some domains known in advance) of boundary problems. Wavelet analysis provides effective and popular tool for such researches. Solution of the considering problem within multilevel wavelet analysis is represented as a composition of local and global components. 


\subsection{Educational activities}

Leading specialists of SRC "StaDyO" are closely involved in development, updating and realization of Master of Science programs (in the fields of "Applied Mathematics" and "Construction") and PhD programs (in the fields of "Informatics and Computer Engineering" and "Engineering and technology of construction"). Besides, we should also mention here the following activities:

- "open lectures", specialized training courses, seminars, counseling (including counseling in the preparation of graduate qualification works);

- training of specialists within the programs of supplementary vocational education in the fields of large-span and high-rise buildings, underground structures, nuclear, thermal and hydroelectric power stations, pipeline systems for various purposes etc);

- organization and development of scientific research \& educational centers and laboratories in leading Russian universities;

- organization and participation in Russian and international scientific events (conferences, symposiums, seminars, etc.);

- preparation of textbooks, tutorials and monographs on topical problems of mathematical and computer simulation of the condition of buildings, structures and complexes.

\section{EXPERIENCE IN THEORETICAL AND PRACTICAL COMPUTATIONAL ANALYSIS}

The reliability of research results, methods, algorithms, software systems and results of analysis is provided by multilevel verification and great (more than 40-years) experience in theoretical and practical computational analysis including the following problems, specified below (Figures 4-21).

1. Three-dimensional thermal and stress-strain state, stability, strength and reliability of pipelines, technological, electrotechnical and lifting-transport equipment, machines and mechanisms, structures, coupled systems "equipment - pipelines", "foundation - overground structure", "foundation subground structure" of buildings, facilities and complexes, with allowance for design and actual load combinations (including temperature loads, static loads, wind loads, operational load (vibrations), special dynamic loads (seismic, shock-wave, emergency and other)):

- reactor compartments, engine rooms, generator halls, turbine buildings, reserve diesel power plants and cooling towers of nuclear power plants (NPP) and waste storages (Armenian, Kursk, Smolensk, Chernobyl, Leningrad, Ignalina, Bilibino, Novovoronezh, Kola, Balakovo, Volgodonsk, Kalinin, Zaporozhye, Beloyarsk, Lovisa, Kozloduy, Belene, Paksh, Temelin, Stendal, Kudankulam, Tianwan, Bushehr, new generation NPP (AS-NP 500, AS-NP 1000, NP 2006, NPP with WWER-TOI, etc.));

- arched, gravity and earth dams, underground structures and buildings of hydroelectric power stations (SayanoShushenskaya, Krasnoyarskaya, Bratskaya, Boguchanskaya, Zeyskaya, Bureyskaya, Vilyuyskaya, Katun, Chirkeiskaya, Volzhskaya, Kamskaya, Inguri, Khudoni, Namakhvani, Kurpsai, Nurek, Rogun, Plyavinskaya , Gekhi, Hoabin, Kapanda, Teri, Tang-E-Duk, etc.), hydroelectric pumped storage power stations (Zagorskaya), tidal hydroelectric stations, coast protection structures, other hydraulic strctures;

- unique and typical buildings and structures of civil engineering (roof of Grand Sports Arena of Luzhniki Olympic Complex (Moscow), the monument to the 300th anniversary of the Russian fleet (Moscow), underground parking of shopping and entertainment mall "Manezhnaya Square" (Moscow), sports and fitness complex "Aquadrom", ice stadium "Megasport" located on Kho- 

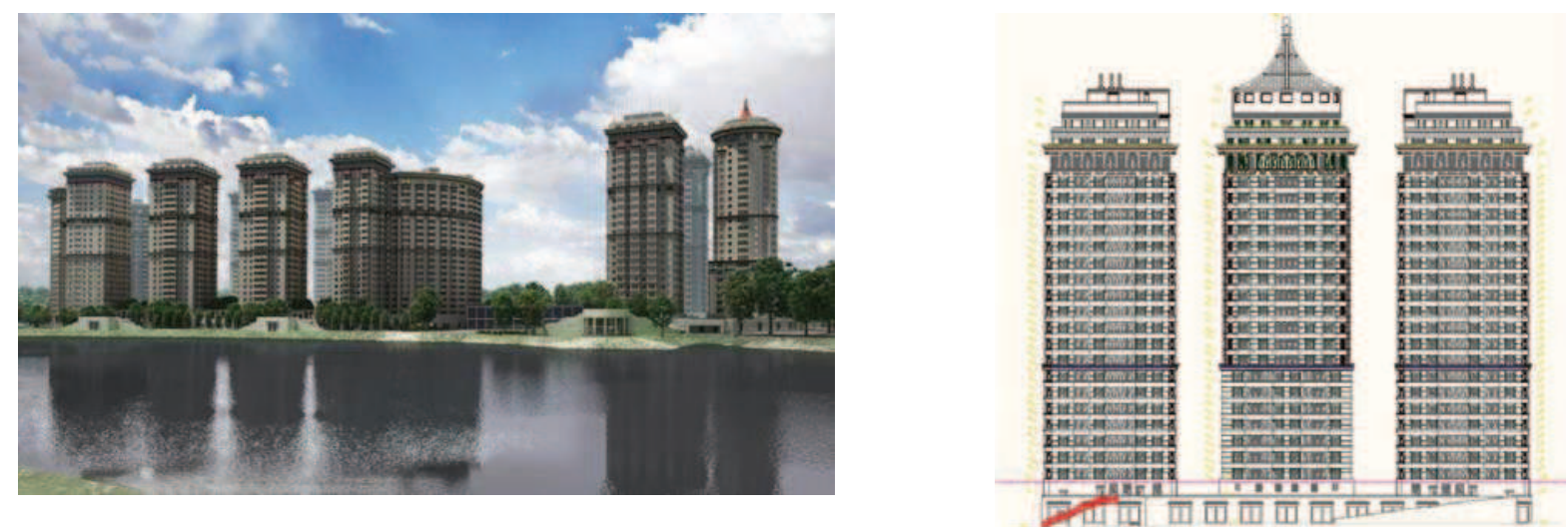

Geometrical model

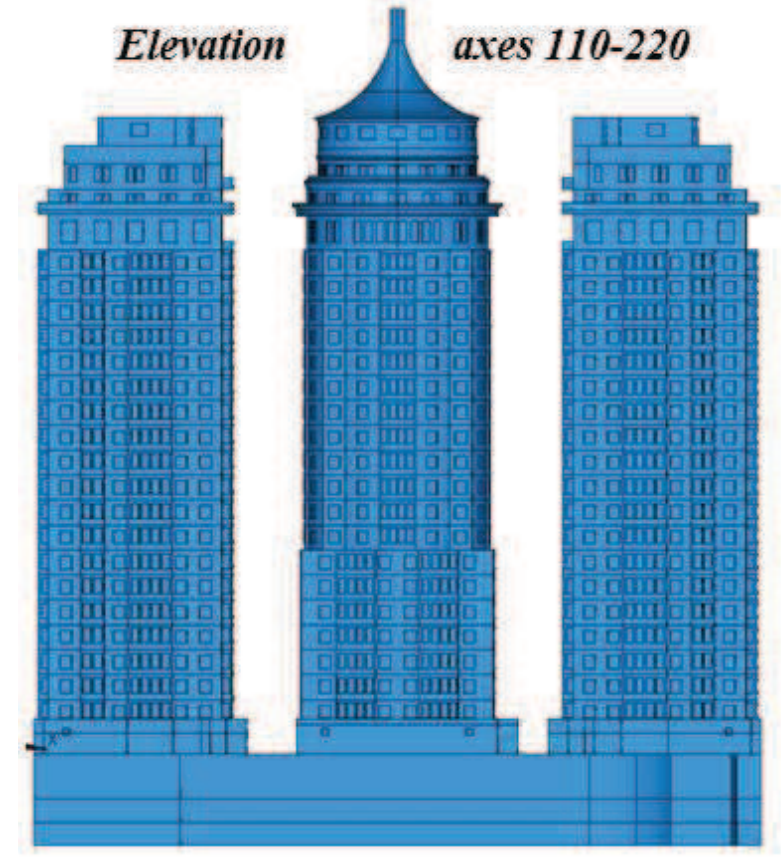

$=$

\section{View from the West}

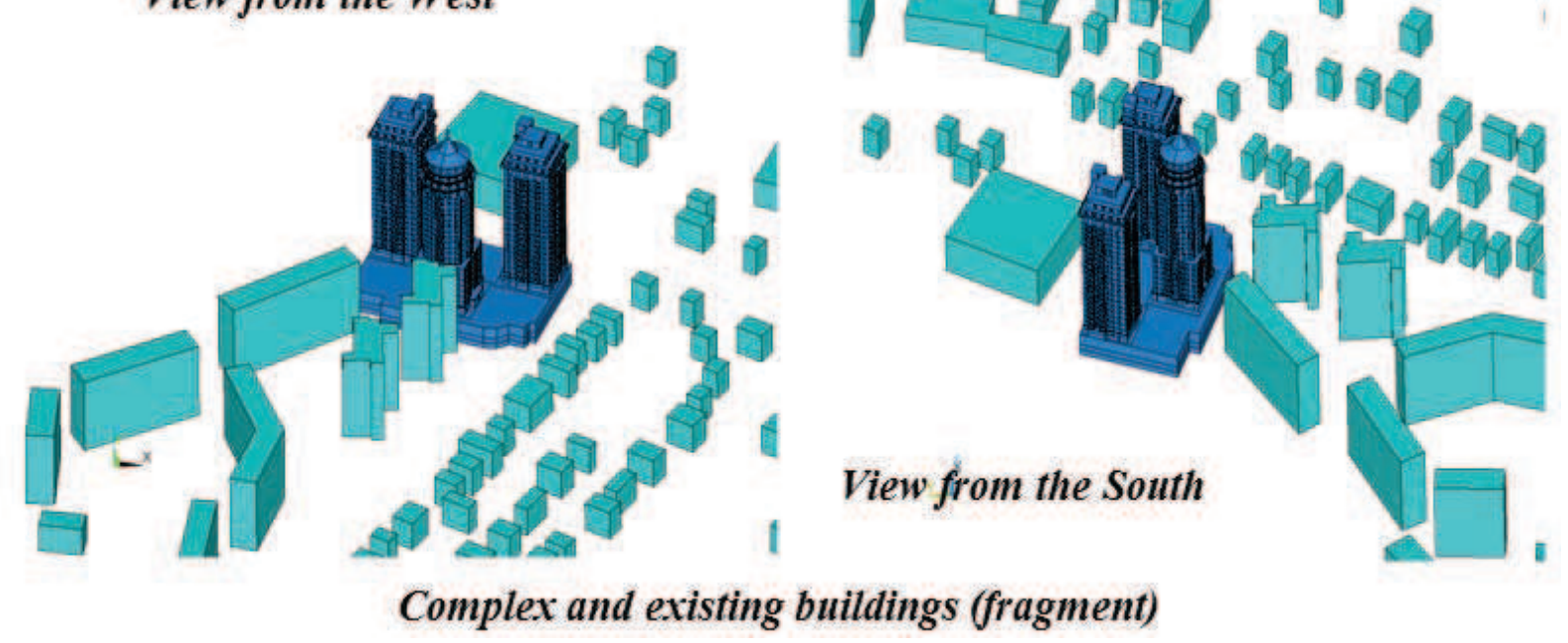

Figure 4. Sample of computing of wind loads on load-bearing and facade structures and pedestrian comfort of buildings of a residential complex, located at Pushkino, Moscow Region (ANSYS CFD). 

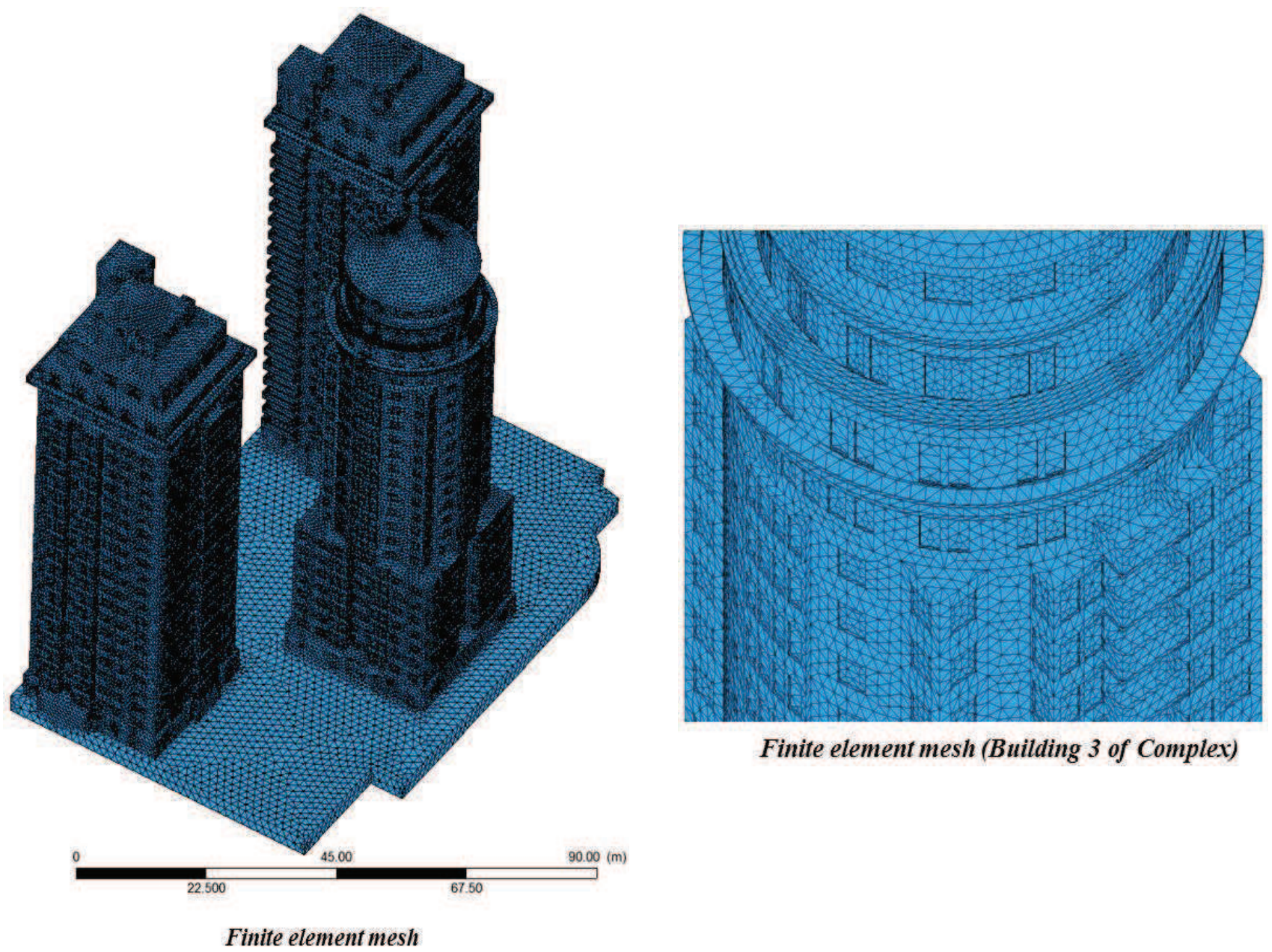

Finite element mesh (Building 3 of Complex)

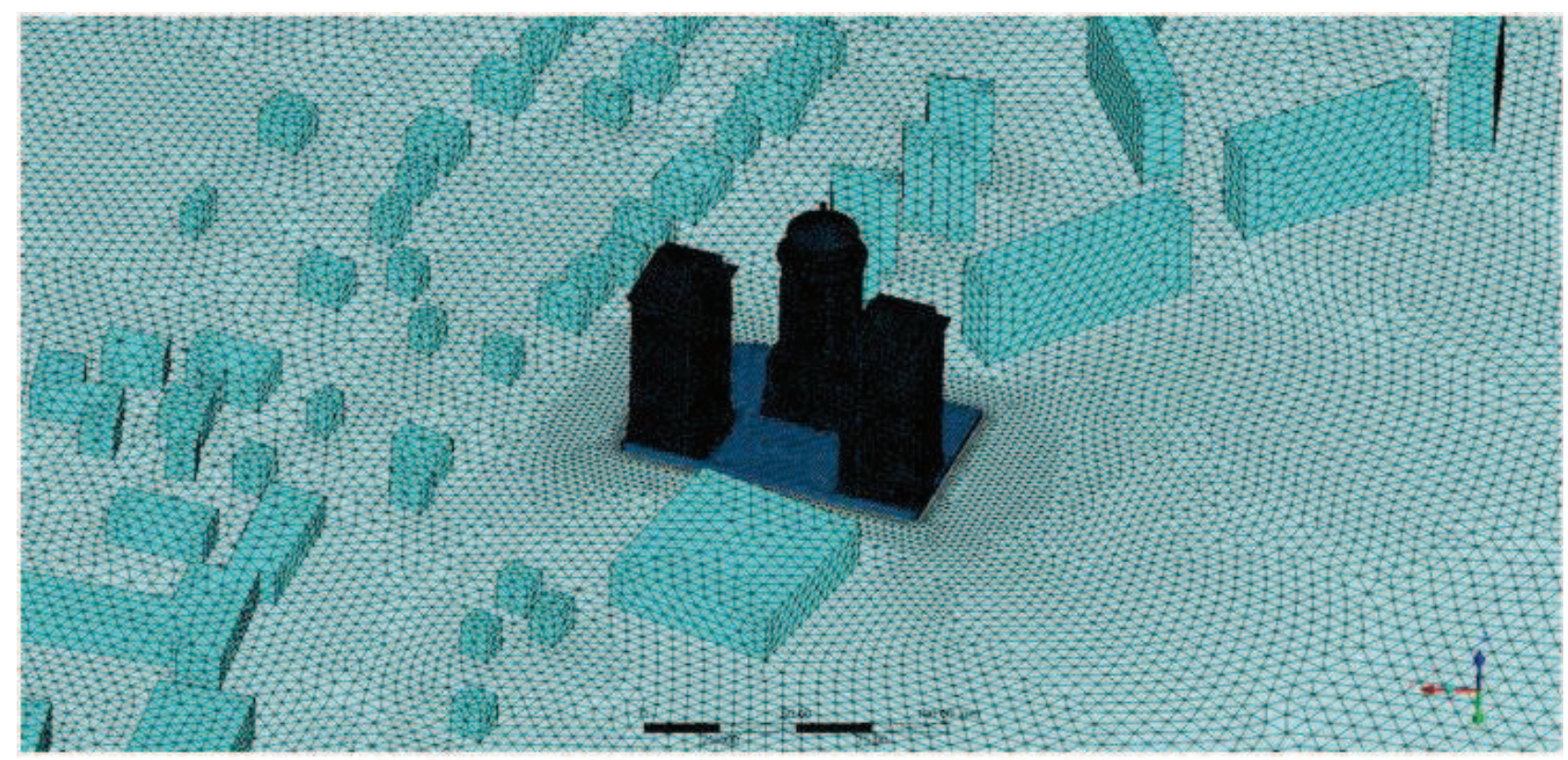

\section{Approximation mesh on the surrounding buildings and ground}

Figure 5. Sample of computing of wind loads on load-bearing and facade structures and pedestrian comfort of buildings of a residential complex, located at Pushkino, Moscow Region (ANSYS CFD). 
Contemporary Problems of Numerical Modelling of Unique Structures and Buildings
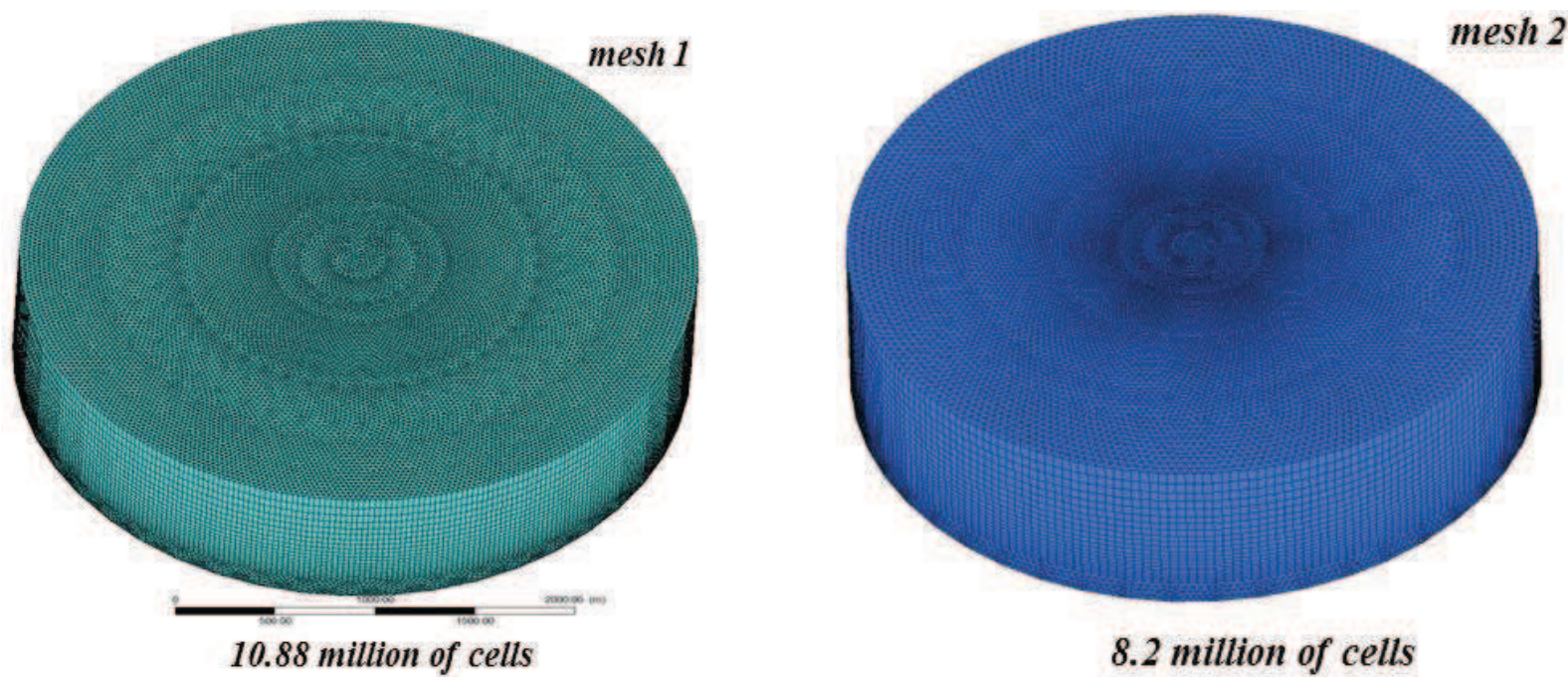

8.2 million of cells

Finite element meshes of the computational domain.

Mesh 1 is used for computing of wind loads on façade and load-bearing structures

of the Complex. Mesh 2 is used for assessments of pedestrian comfort in the area of the Complex.
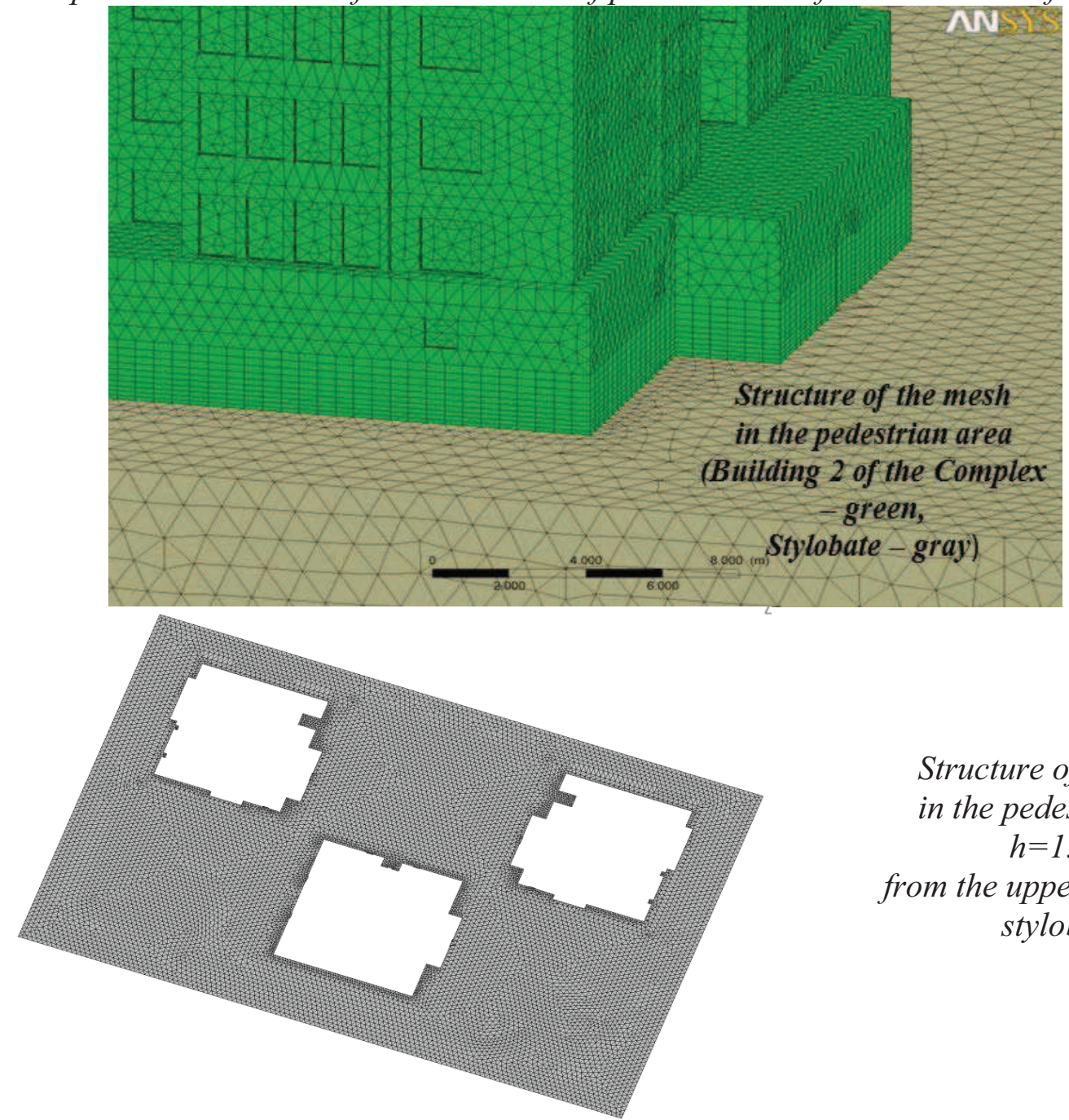

Structure of the mesh in the pedestrian area $h=1.5 \mathrm{~m}$ from the upper level of the stylobate

Figure 6. Sample of computing of wind loads on load-bearing and facade structures and pedestrian comfort of buildings of a residential complex, located at Pushkino, Moscow Region (ANSYS CFD). 

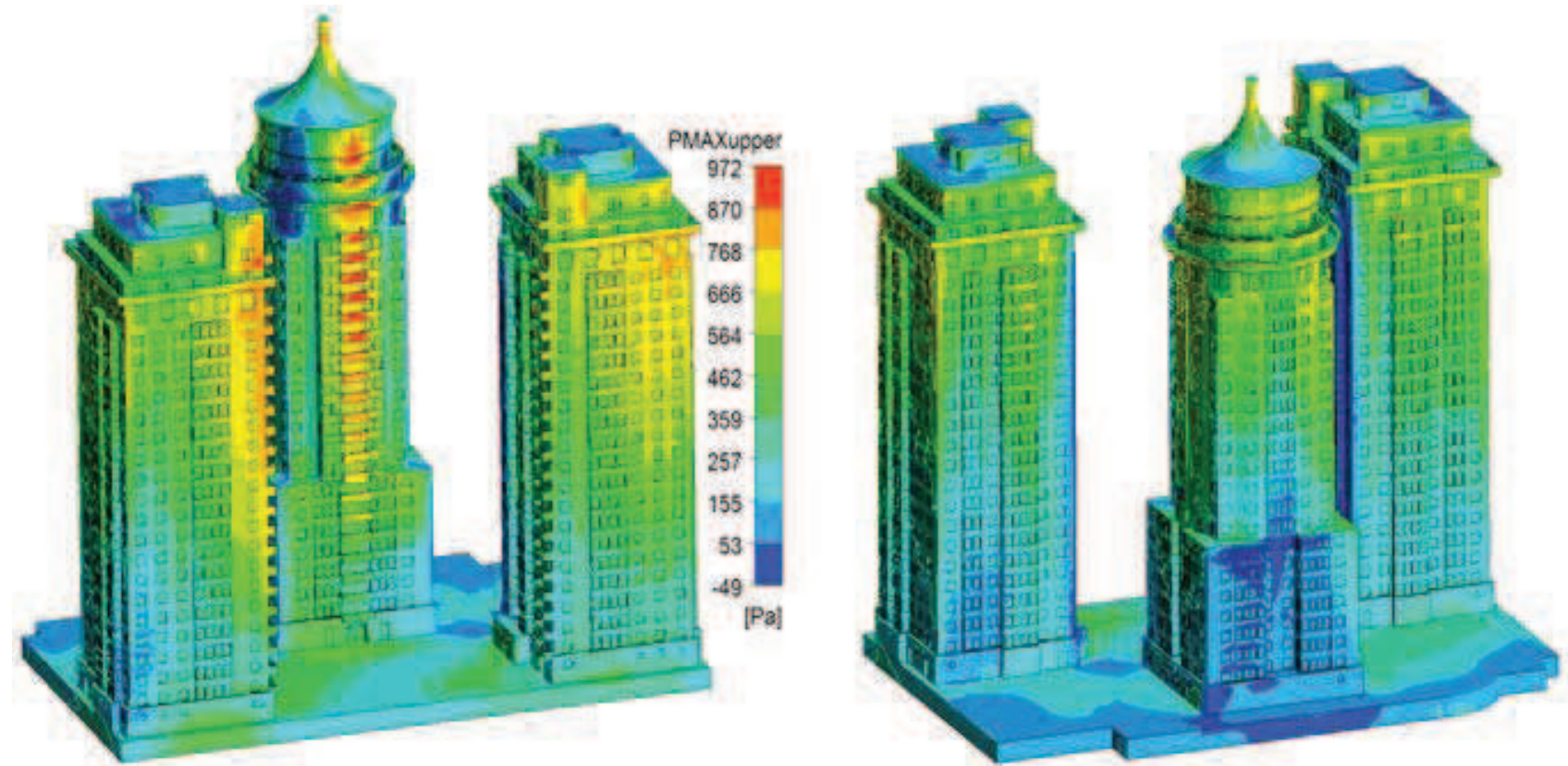

The upper envelope of the maximum values of wind pressure $(\mathrm{Pa})$ on facade structures of the Complex (Maximum - 972 Pa, Minimum - -49 Pa).
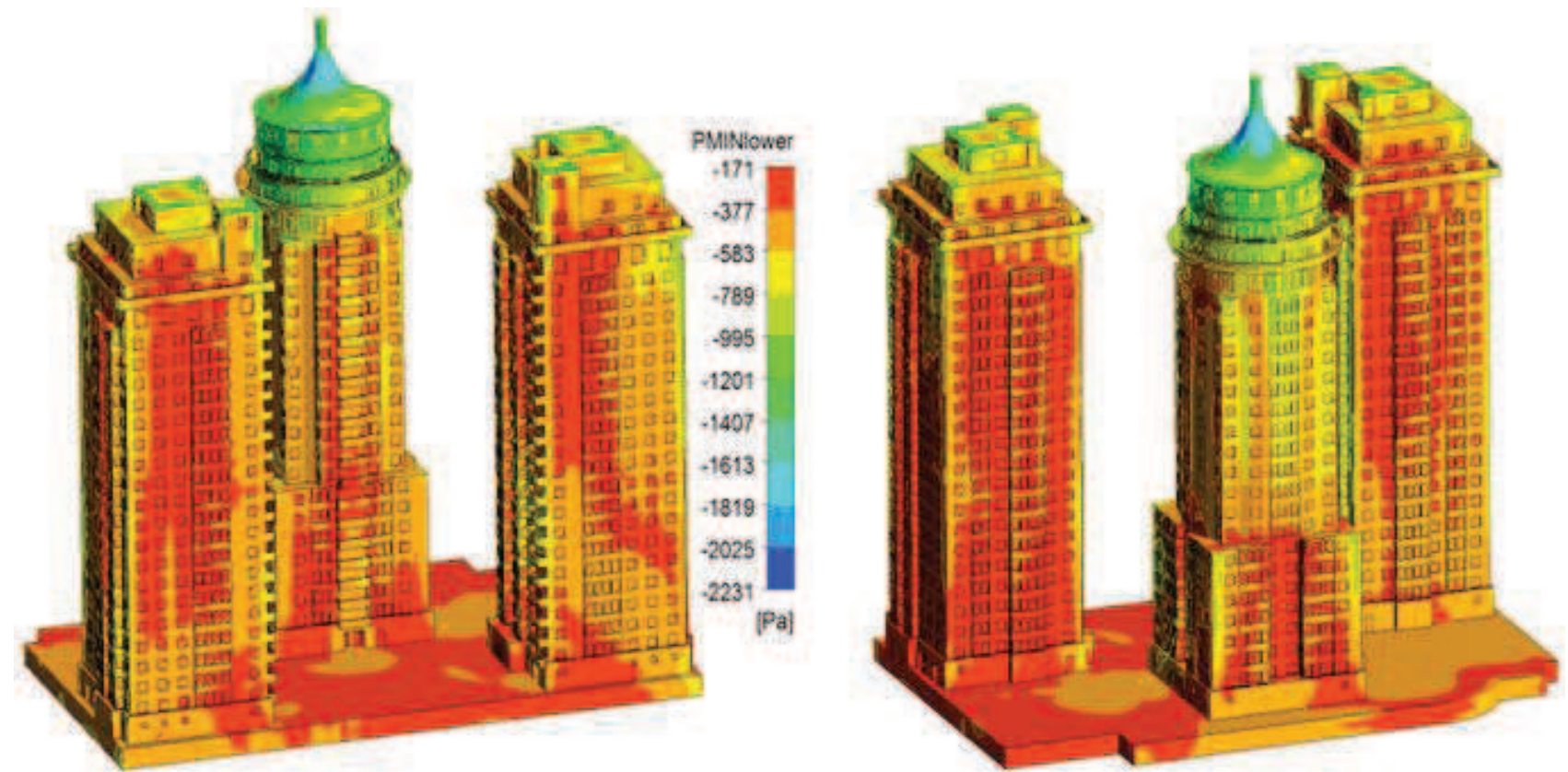

The lower envelope of the maximum values of wind pressure ( $\mathrm{Pa}$ ) on facade structures of the Complex (Maximum - -171 Pa, Minimum - -2231 Pa).

Figure 7. Sample of computing of wind loads on load-bearing and facade structures and pedestrian comfort of buildings of a residential complex, located at Pushkino, Moscow Region (ANSYS CFD). 

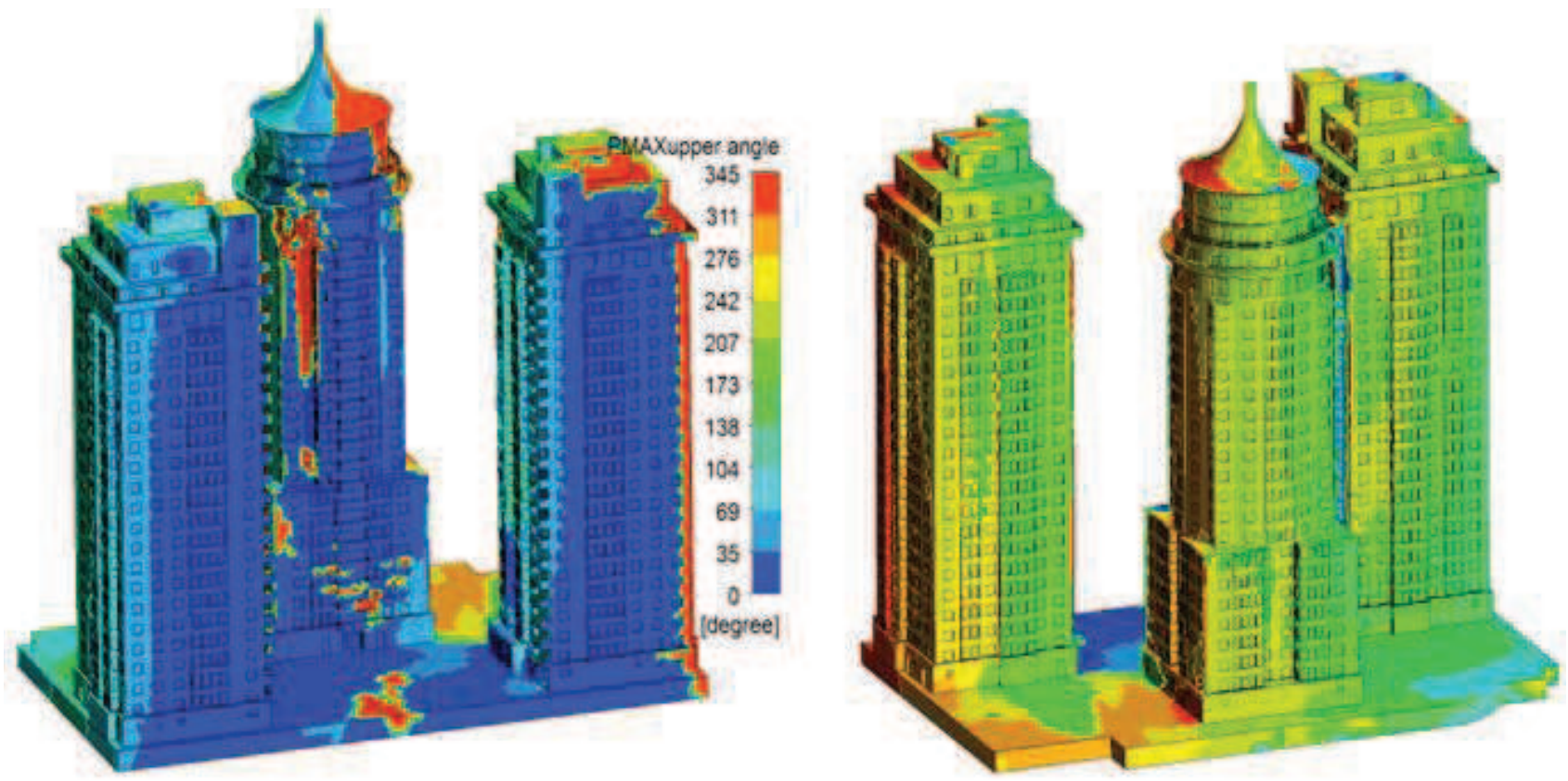

Angle of wind impact $\left(^{\circ}\right)$, at which the upper envelope of the maximum values of wind pressure is realized on the facade structures of the Complex
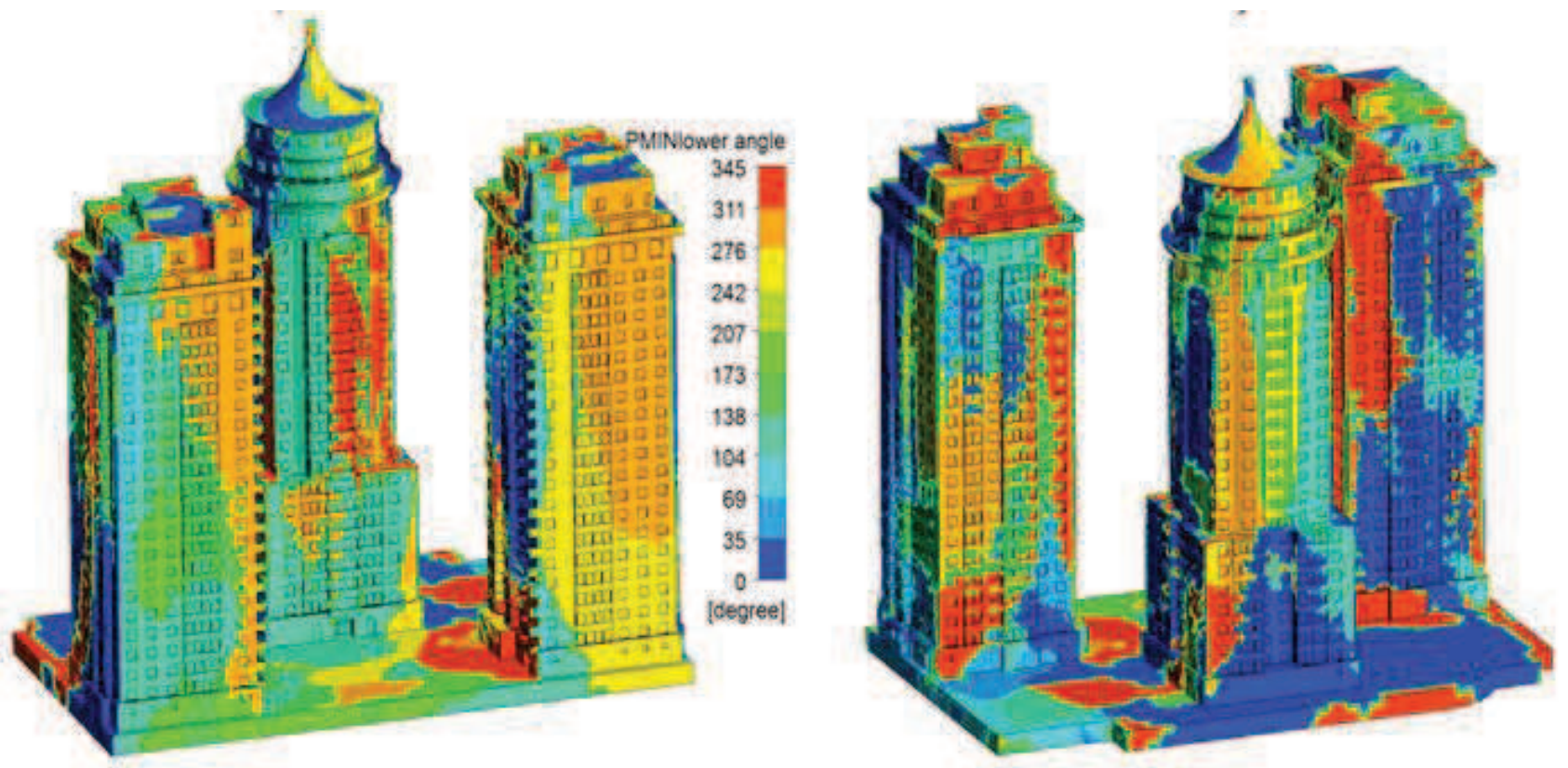

Angle of wind impact ( $\left.{ }^{\circ}\right)$, at which the lower envelope of the minimum values of wind pressure is realized on the facade structures of the Complex

Figure 8. Sample of computing of wind loads on load-bearing and facade structures and pedestrian comfort of buildings of a residential complex, located at Pushkino, Moscow Region (ANSYS CFD). 


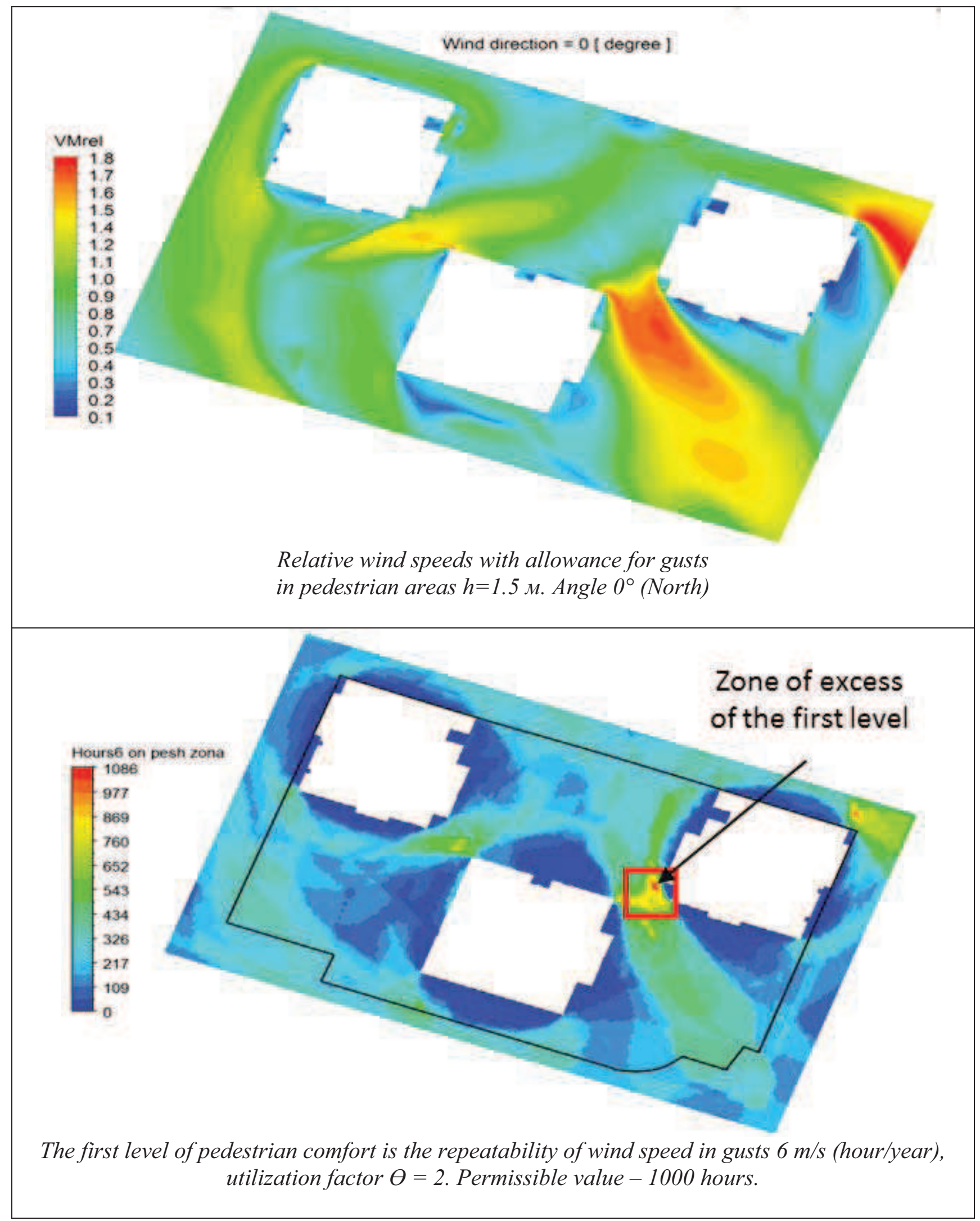

Figure 9. Sample of computing of wind loads on load-bearing and facade structures and pedestrian comfort of buildings of a residential complex, located at Pushkino, Moscow Region (ANSYS CFD). 


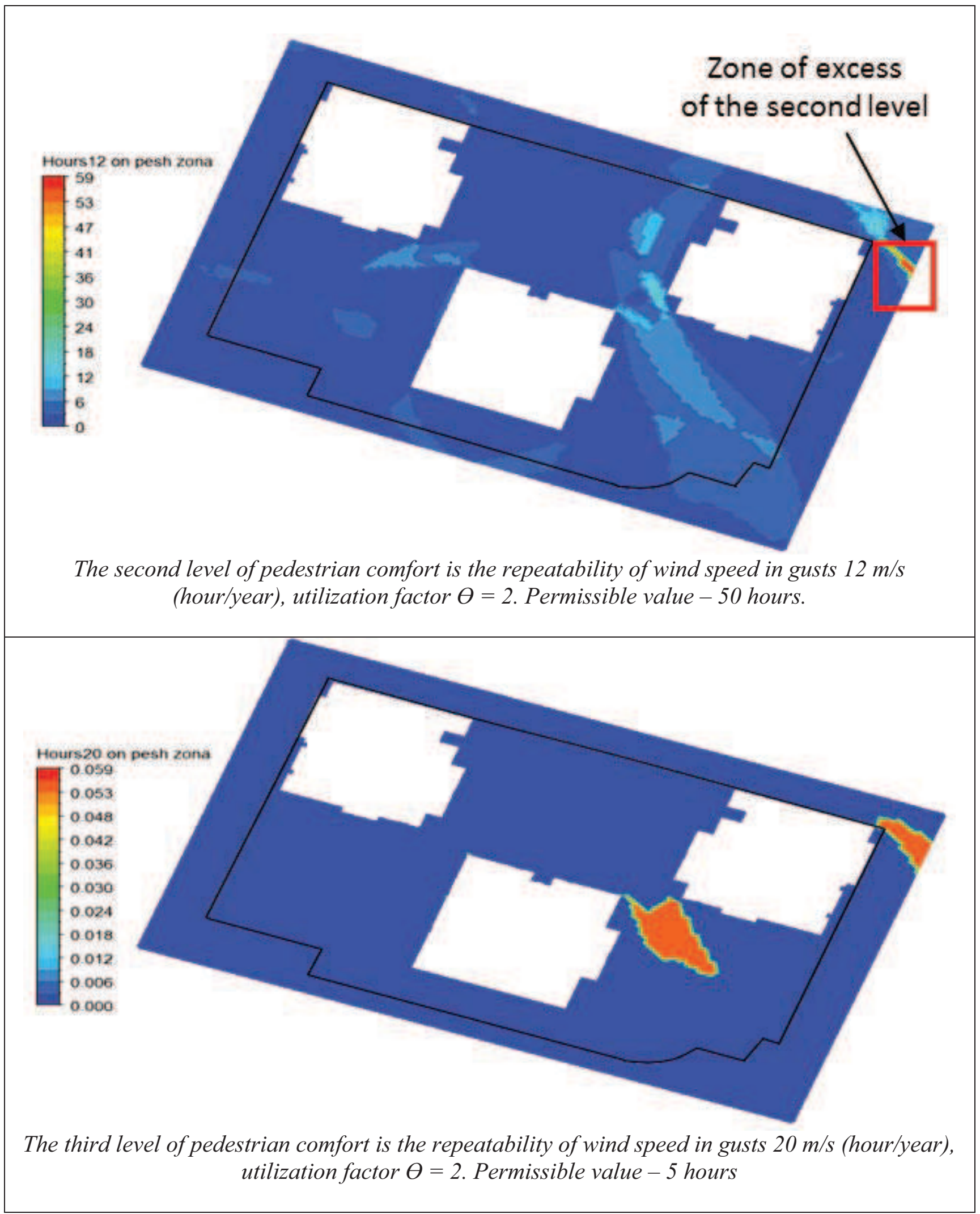

Figure 10. Sample of computing of wind loads on load-bearing and facade structures and pedestrian comfort of buildings of a residential complex, located at Pushkino, Moscow Region (ANSYS CFD). 

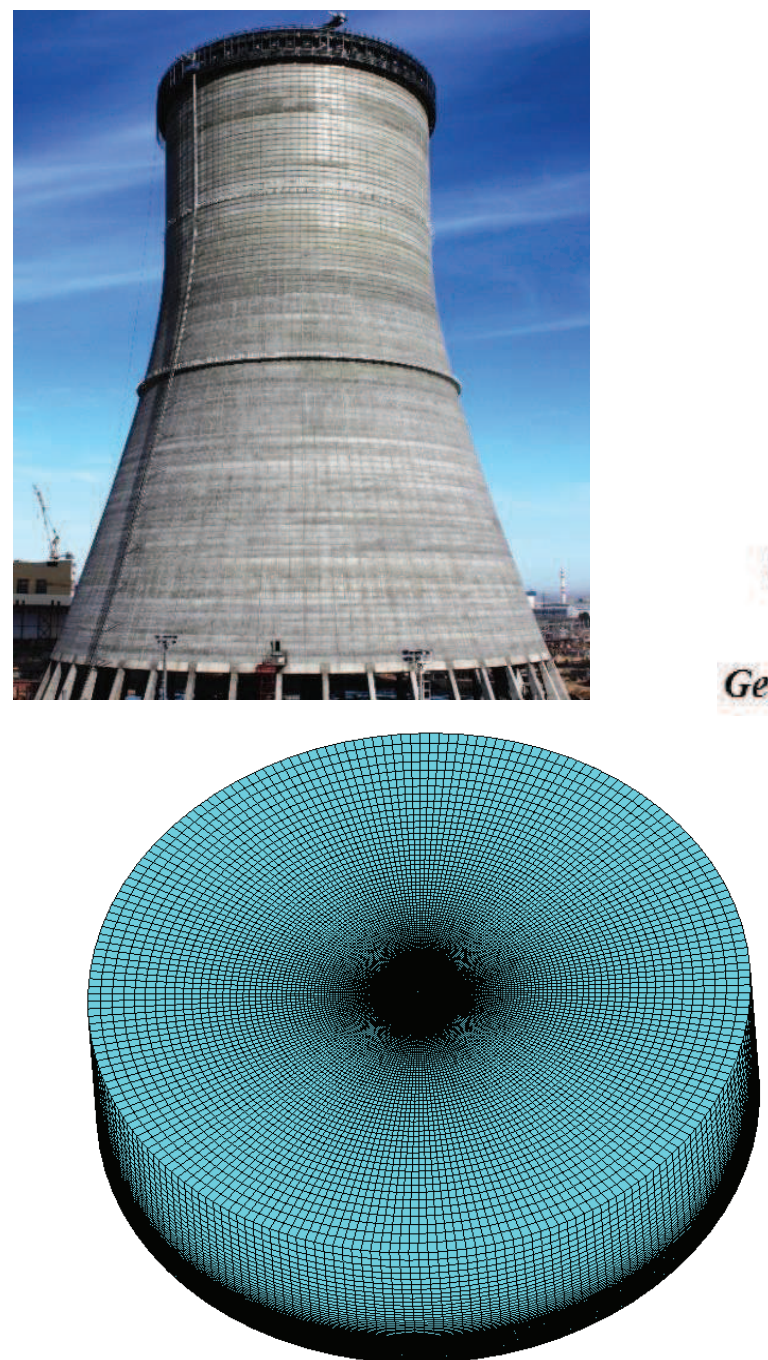

Computational domain(5.28 millions of elements)

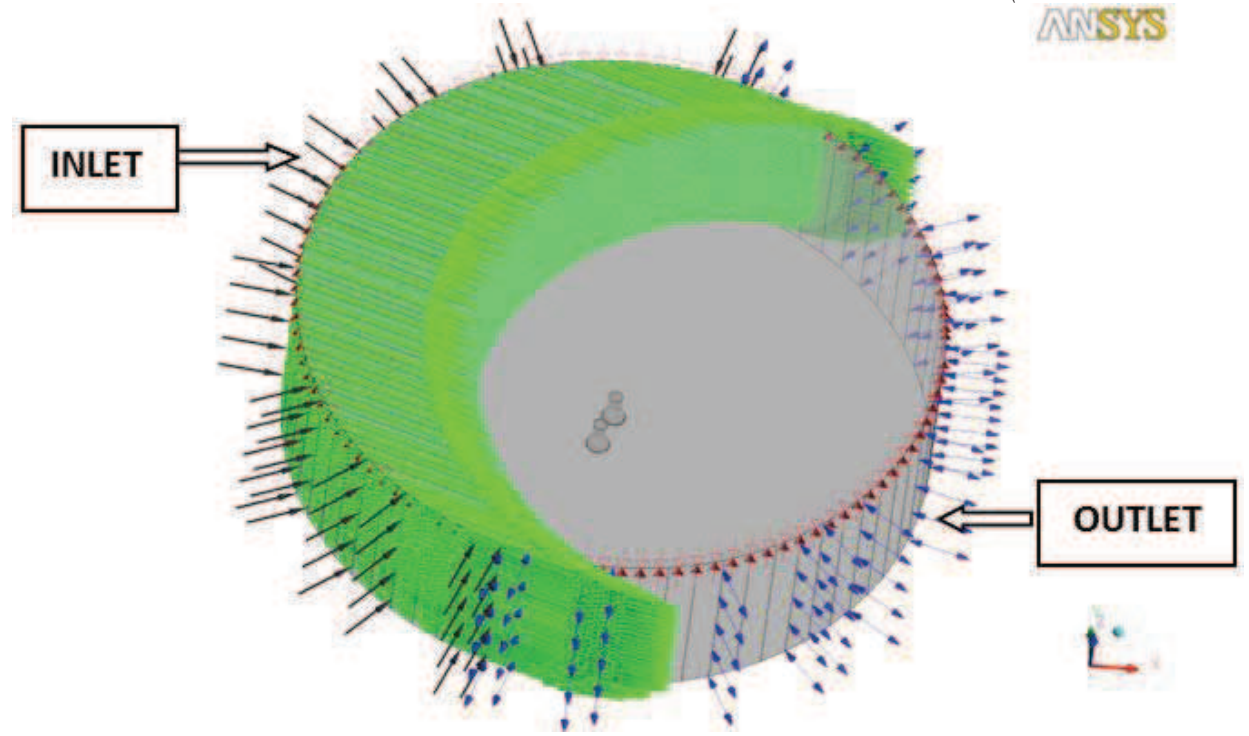

Computational domain with the indicated boundary conditions. Angle of wind impact $0^{\circ}$

Figure 11. Wind aerodynamics. Evaporative cooling towers of Novovoronezh nuclear power plant-2 (sample). Three-dimensional CFD-model (ANSYS CFD). 

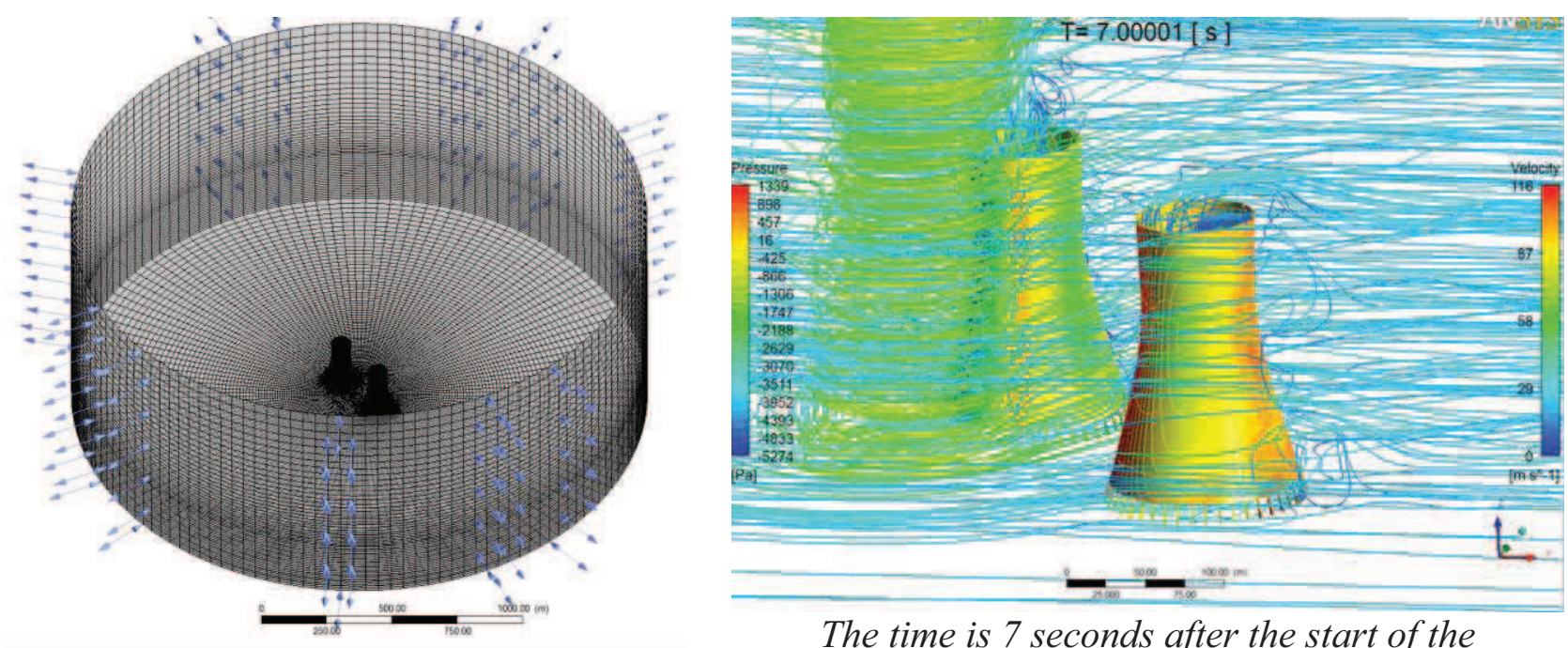

The time is 7 seconds after the start of the "movement" of the tornado. Pressure (Pa) on the surface of the cooling towers, streamline pattern.

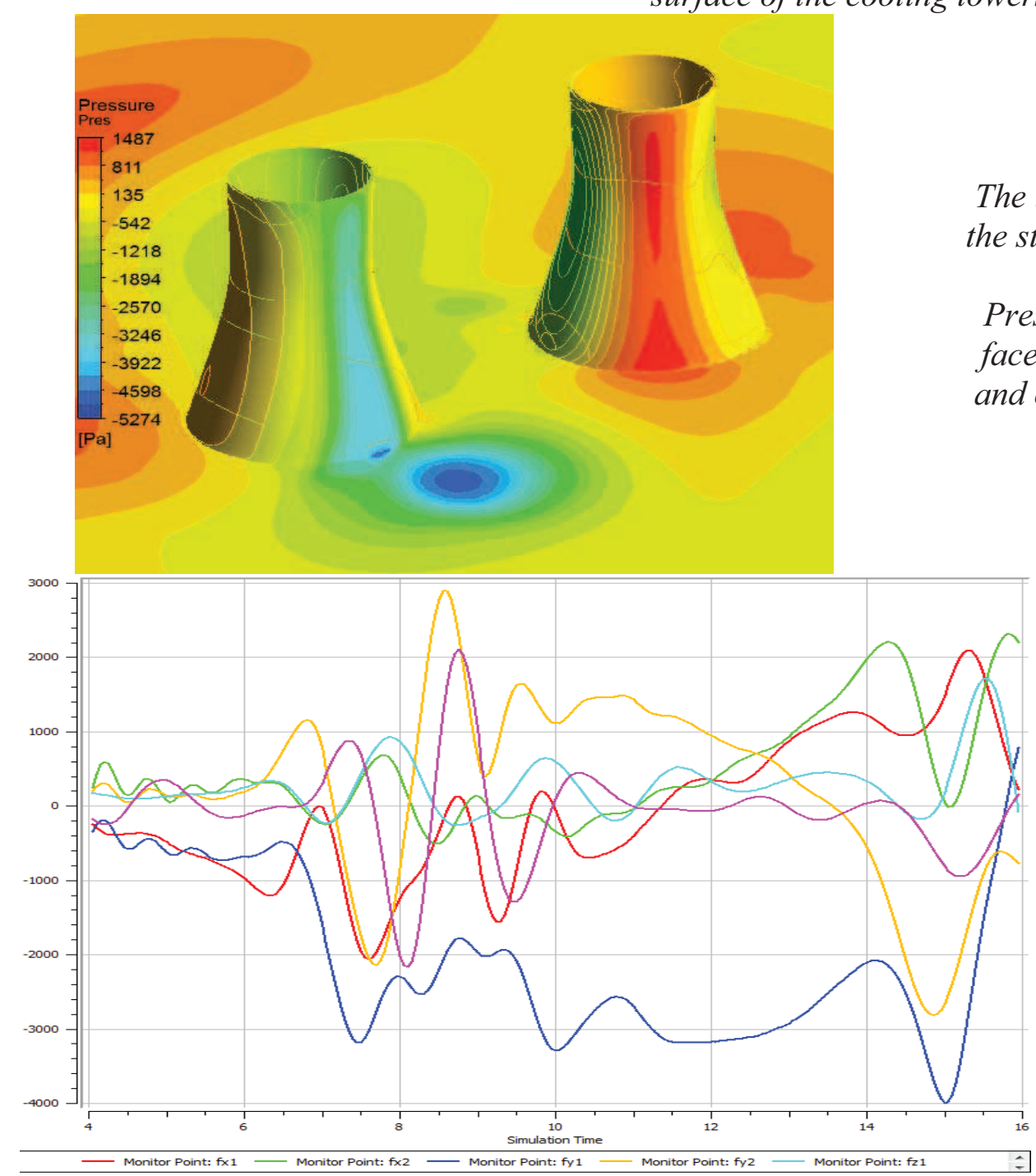

Total loads (ton-force) $F X$ and $F Y$ on the first and the second cooling towers caused by tornado $(s)$.

Figure 12. Wind aerodynamics. Evaporative cooling towers of Novovoronezh nuclear power plant-2 (sample). Three-dimensional CFD-model (ANSYS CFD). 


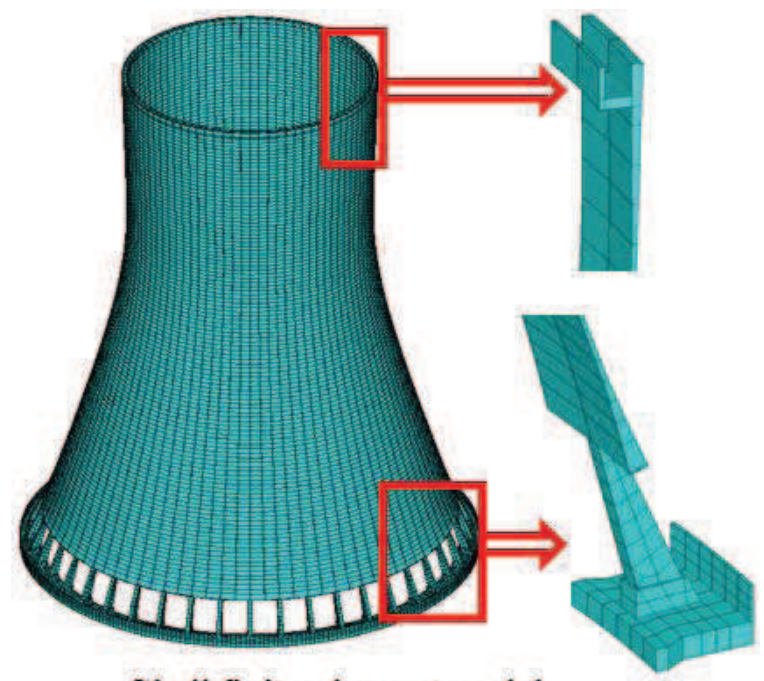

Shell finite element model

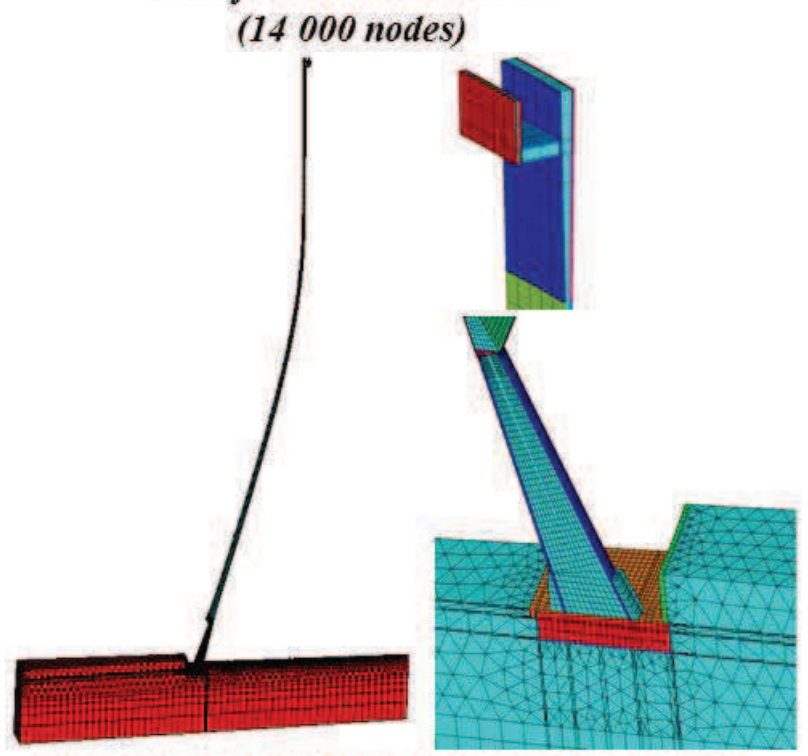

Three-dimensional finite element model of sector $1 / 88$ part with soil foundation (36 000 nodes)

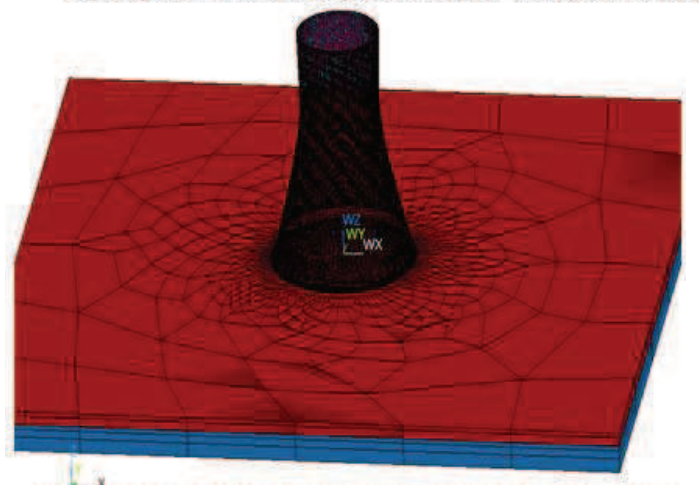

Simplified finite element model of the system

"Dynamic soil foundation - cooling tower (shell) with allowance for contact interaction (35 000 nodes)

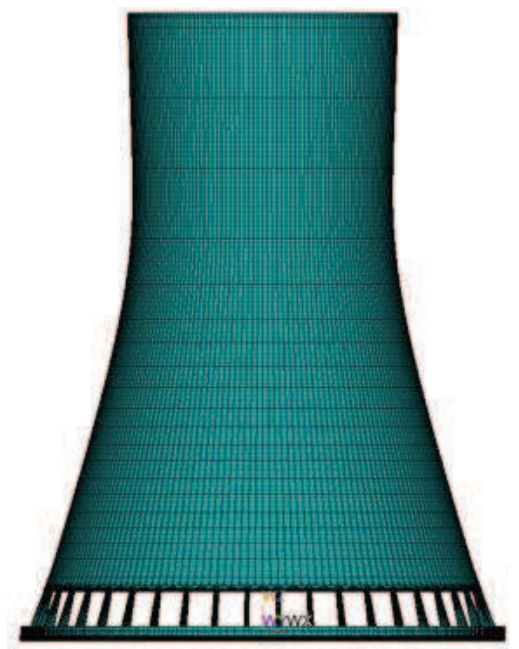

Three-dimensional finite element model (724000 nodes)

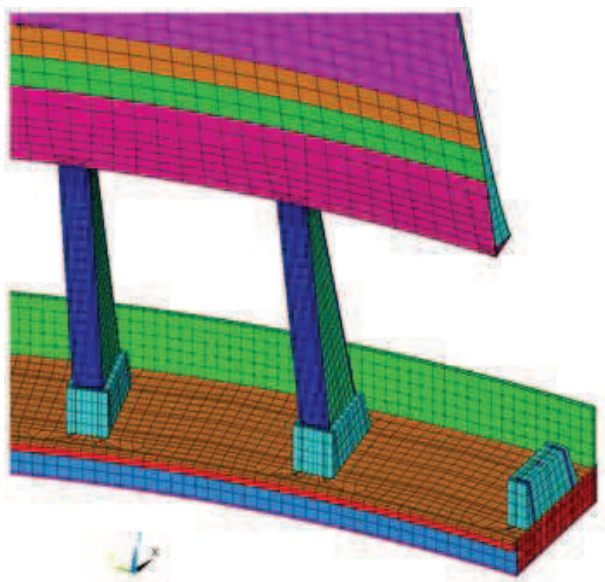

Three-dimensional finite element model for analysis of emergency situation (49 000 nodes)

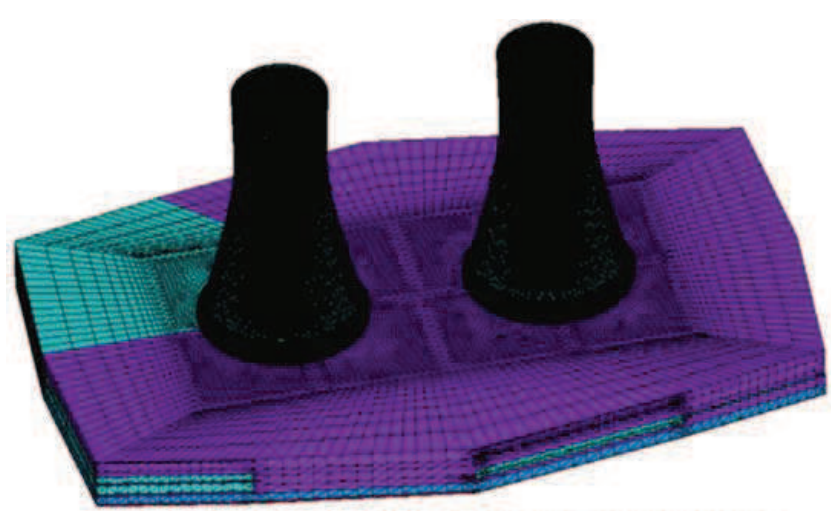

Three-dimensional finite element model of system "soil foundation - cooling tower" (1 300000 nodes)

Figure 13. Wind aerodynamics. Evaporative cooling towers of Novovoronezh nuclear power plant-2 (sample). Three-dimensional CFD-model (ANSYS CFD). 

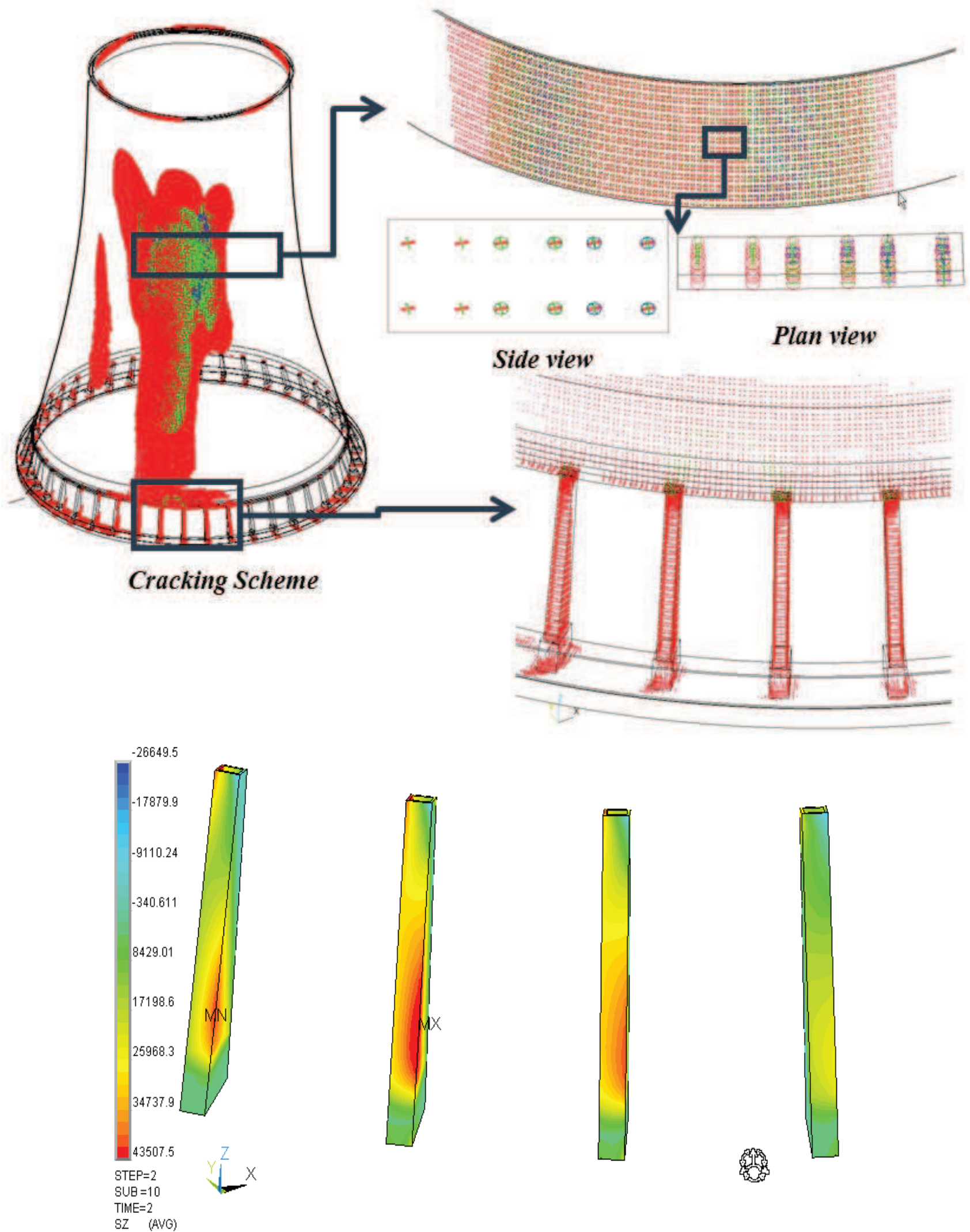

Stress (tnf/ $\mathrm{m}^{2}$ ) in column reinforcement.From -26650 to $43507 \mathrm{tnf} / \mathrm{m}^{2}$

Figure 14. Wind aerodynamics. Evaporative cooling towers of Novovoronezh nuclear power plant-2 (sample). Three-dimensional CFD-model (ANSYS CFD). 


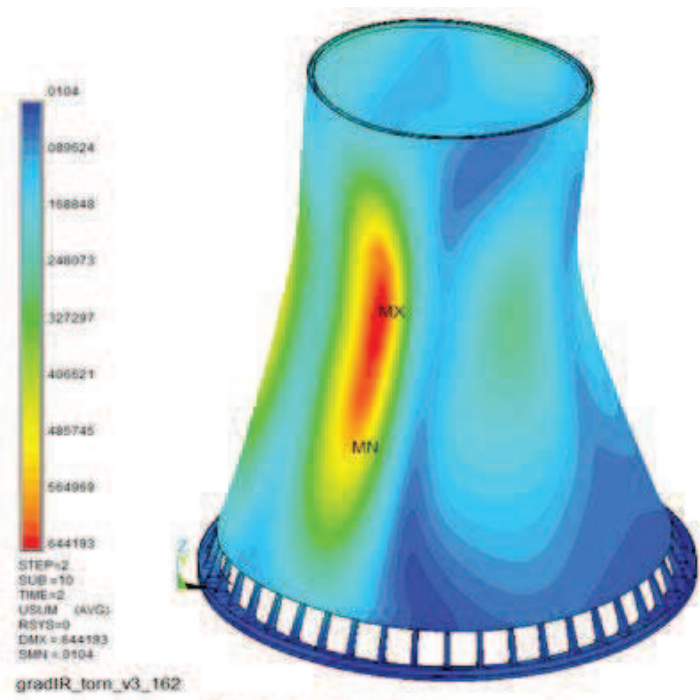

The total displacement, Maximum value $0.64 \mathrm{~m}$
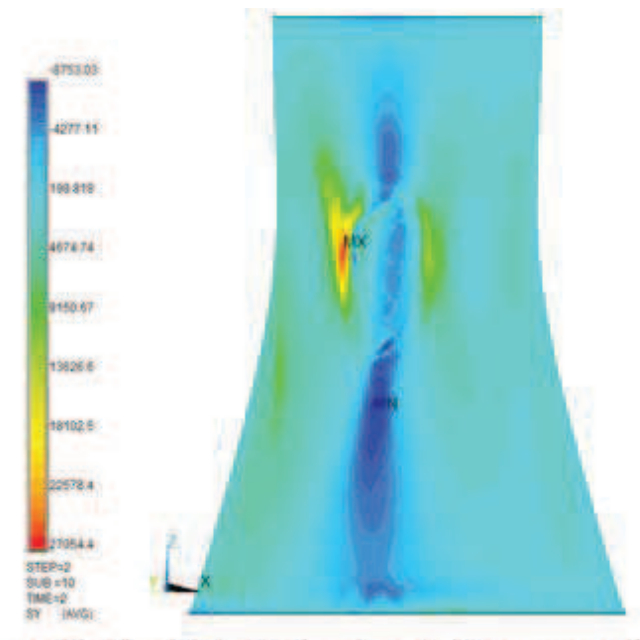

Stress $\left(\mathrm{tnf} / \mathrm{m}^{2}\right)$ in lateral reinforcement of shell. From -8753 to $27054 \mathrm{tnf} / \mathrm{m}^{2}$
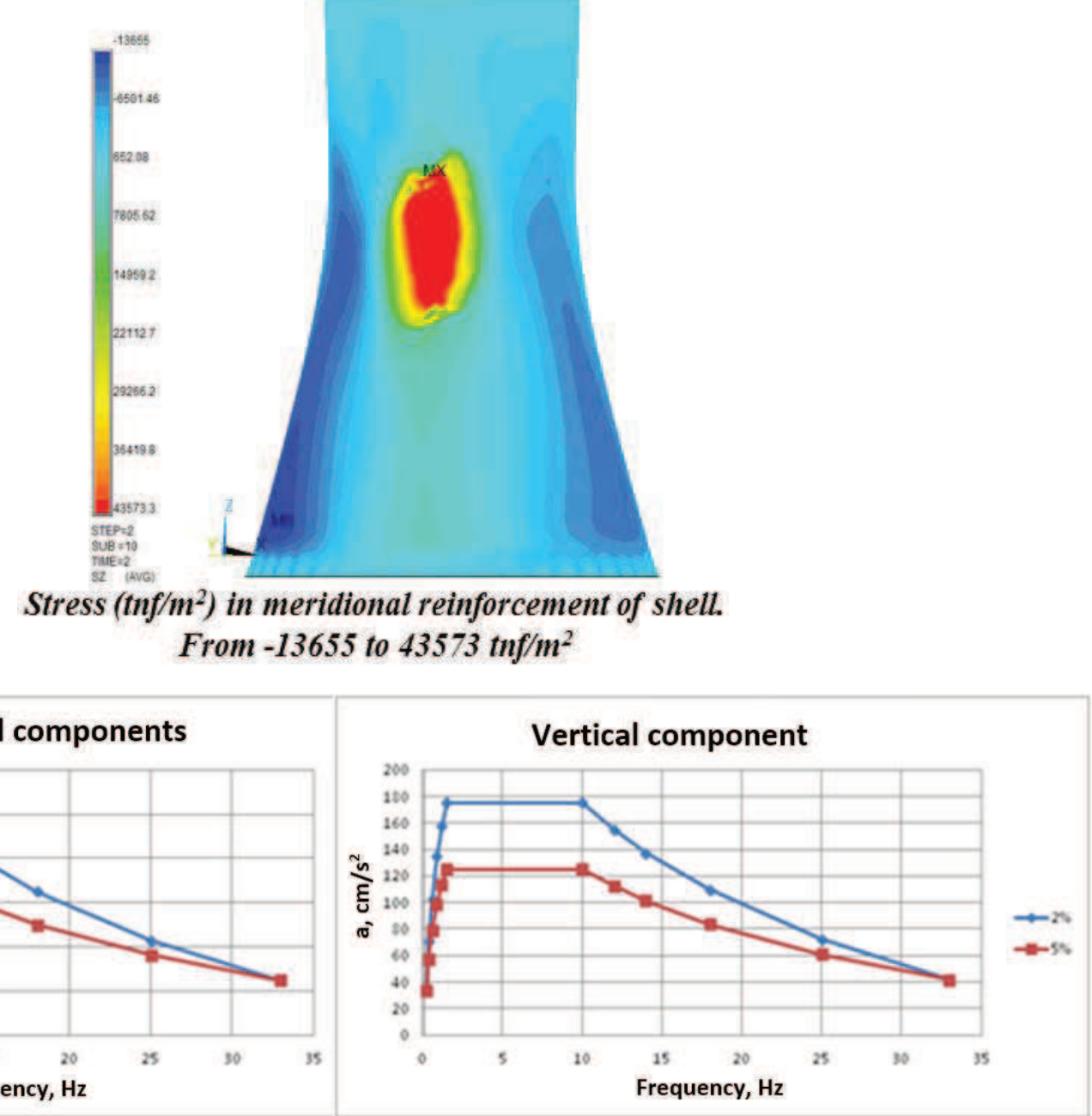

Response spectra (cm/s2) for the Basic NPP-2006 Project, intensity 6 on the MSK-64 scale

Figure 15. Wind aerodynamics. Evaporative cooling towers of Novovoronezh nuclear power plant-2 (sample). Three-dimensional CFD-model (ANSYS CFD). 


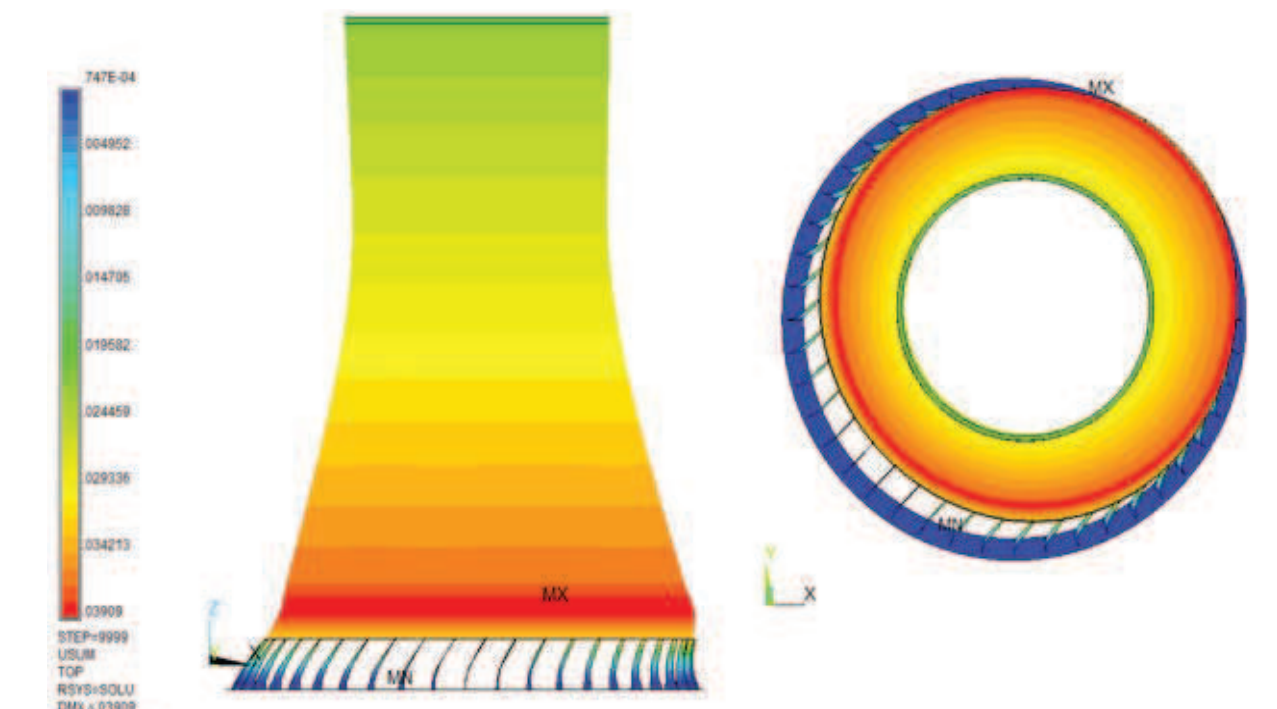

The total displacement, maximum value $0.039 \mathrm{~m}$ Analysis with the use of linear-spectral method
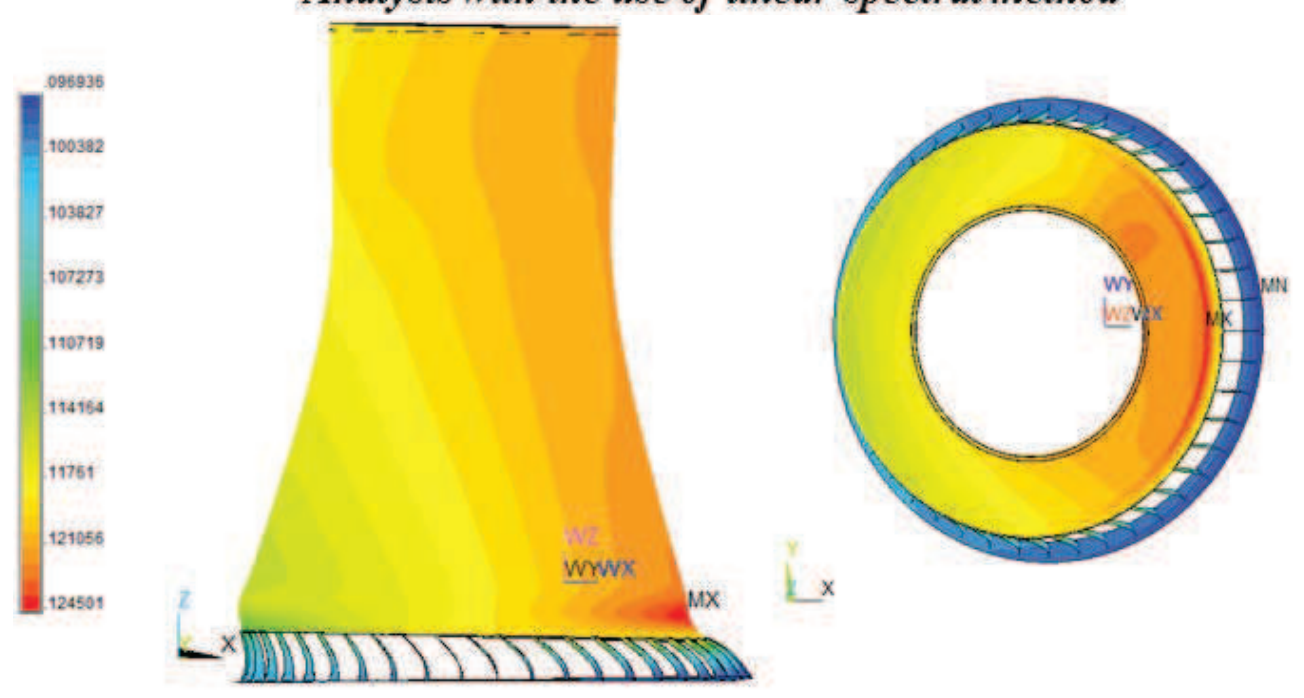

Total displacement $(\mathrm{m})$ at the timet $=8.85 \mathrm{~s}$. Structural analysis with allowance of accelerogram based on direct dynamic method

Figure 16. Wind aerodynamics. Evaporative cooling towers of Novovoronezh nuclear power plant-2 (sample). Three-dimensional CFD-model (ANSYS CFD).

dynka (Moscow), sports complex "Moskvich" (Moscow), indoor swimming pool of the "Iskra" sanatorium (Sochi), ice palace "Bolshoi" (Sochi), bobsleigh track "Sanki" and the ski complex "Gorki" (Sochi, Winter Olympic Games 2014), football stadiums of the World Cup 2018 ("Zenit" (Saint-Petersburg), "Spartak" (Moscow), stadiums located at
Volgograd, Samara, Nizhny Novgorod and Rostov-on-Don); multifunctional high-rise complexes (including Moscow International Business Center "MoscowCity", Poklonnaya (Moscow), Profsoyuznaya (Moscow), Leningradskaya (Moscow), building located at Volgograd, Omsk, Vladivostok, Krasnodar, Kiev, Astana), multi-block shopping and 
Alexander M. Belostotsky, Pavel A. Akimov, Irina N. Afanasyeva, Taymuraz B. Kaytukov
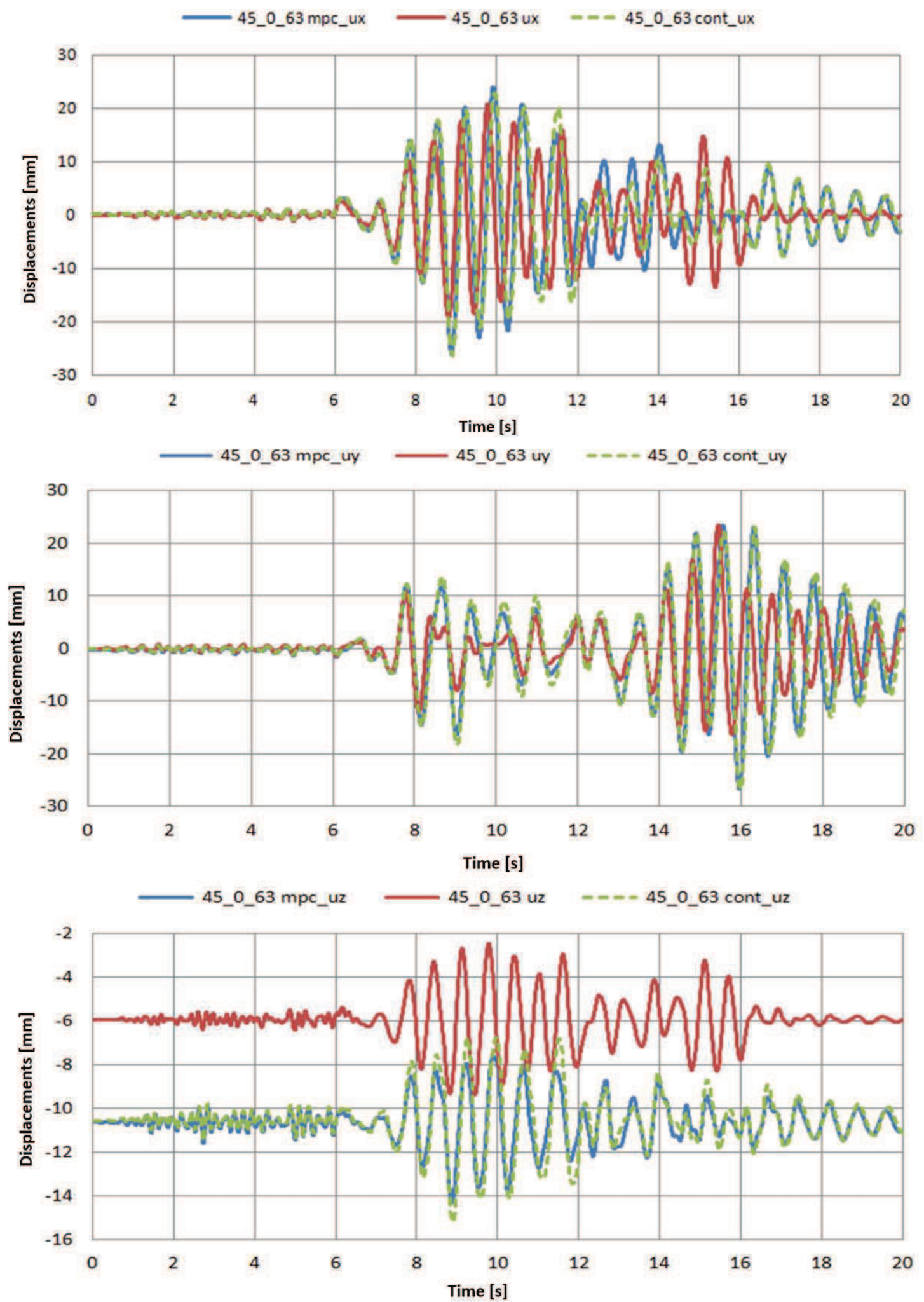

Nodal displacements $U X, U Y, U Z(\mathrm{~mm})$ at a height of $63 \mathrm{~m}$ relative to base

(for three formulations): blue line - "continuous" MPC contact, red line - rigid foundation, green dashed line - standard contact

Figure 17. Wind aerodynamics. Evaporative cooling towers of Novovoronezh nuclear power plant-2 (sample). Three-dimensional CFD-model (ANSYS CFD). 

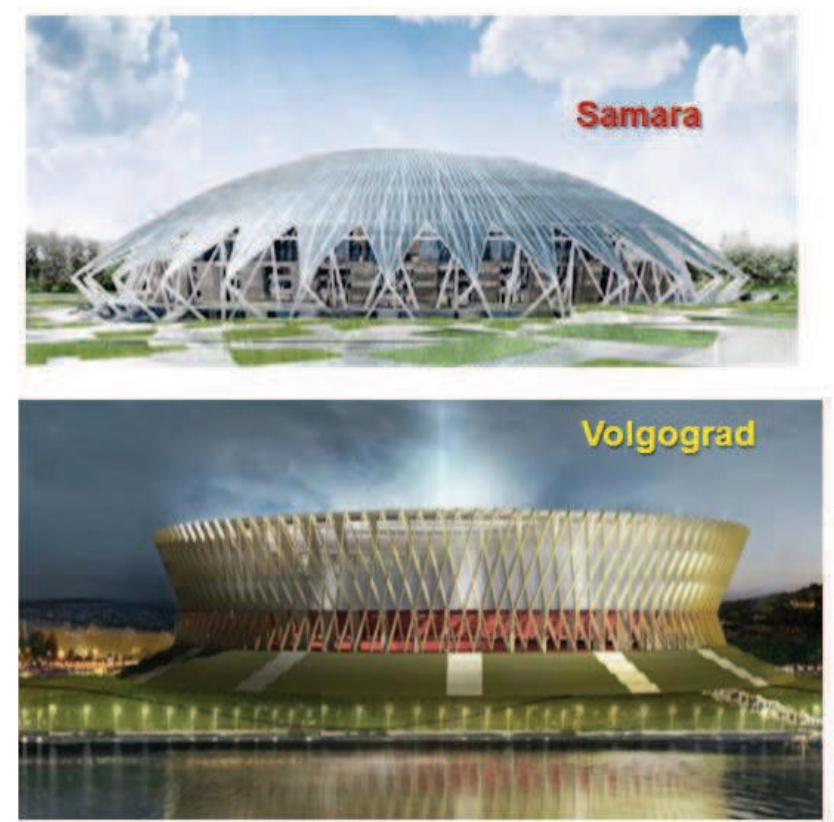

Nizhny Novgorod

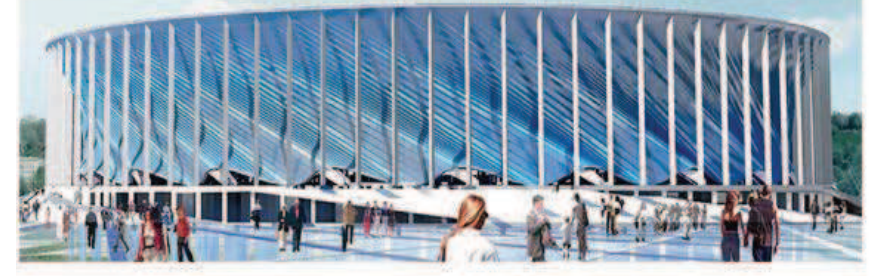

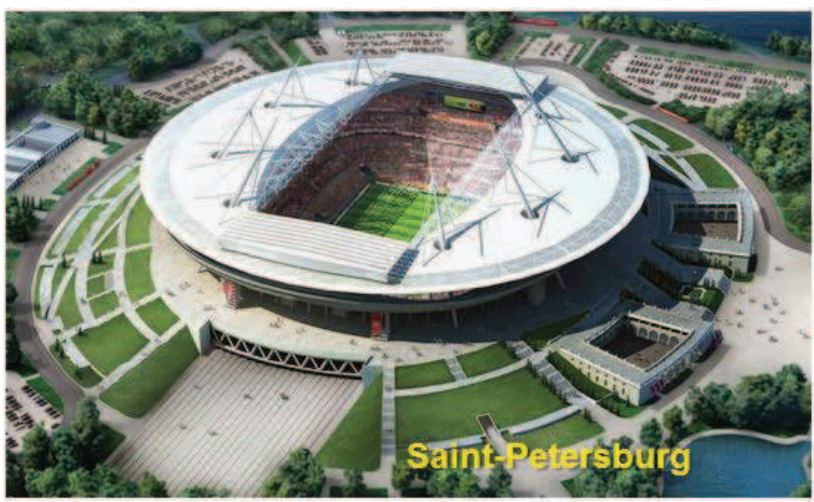
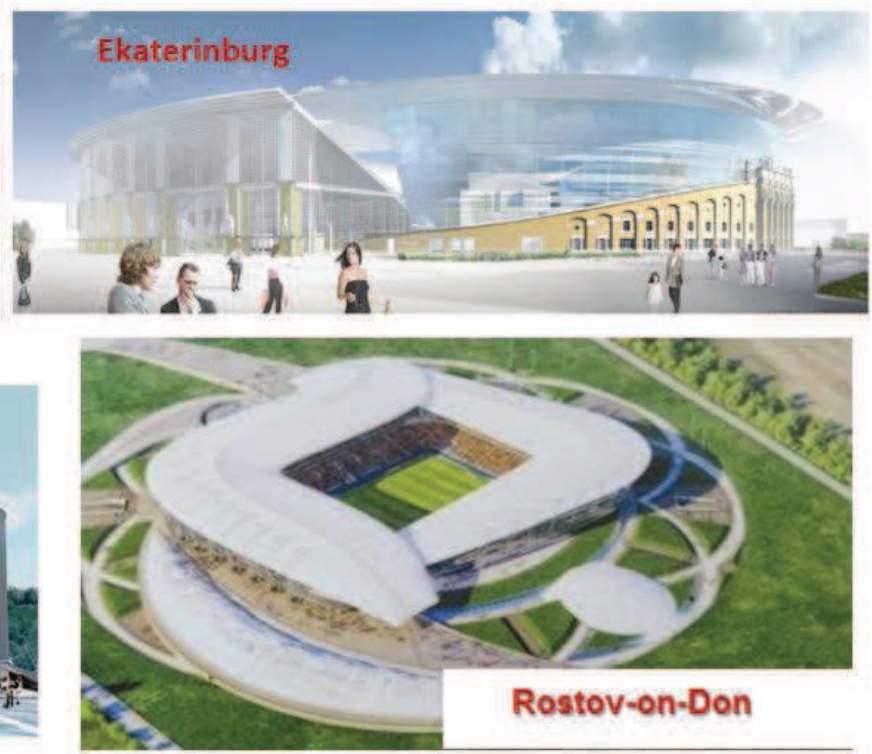

Figure 18. Analysis of stress-strain state, strength and stability of load-bearing structures of football stadiums of the World Cup 2018 (ANSYS). Samples.

entertainment centers, multi-storey panel block sections and monolithic buildings, schools and polyclinics, banners with allowance for initial tension of ropes, wind loads and other factors);

- overground and underground pipelines of heating systems, main oil and gas pipelines, petrochemical and gas pipelines and equipment (analysis of "Sakhalin - Khabarovsk - Vladivostok" gas pipeline system is among the last comprehensive and "breakthrough" researches);

- wind power plants of various types and capacities;

- loating structures and platforms for the offshore extraction of oil and gas;
- arious bio- and nanostructures (for example, double linear and closed DNA (deoxyribonucleic acid) helices).

- - complex mechanical engineering structures, machines and mechanisms including aerospace systems, transport, shipbuilding, power engineering, ferrous and non-ferrous metallurgy, consumer electronics, etc. (analysis of stress-strain state, dynamic response and strength of the coupled system "Science power platform - drive unit - solar batteries" and subsystems of the International Space Station (ISS) "Alpha" at the stages of launch and orbital activity. 

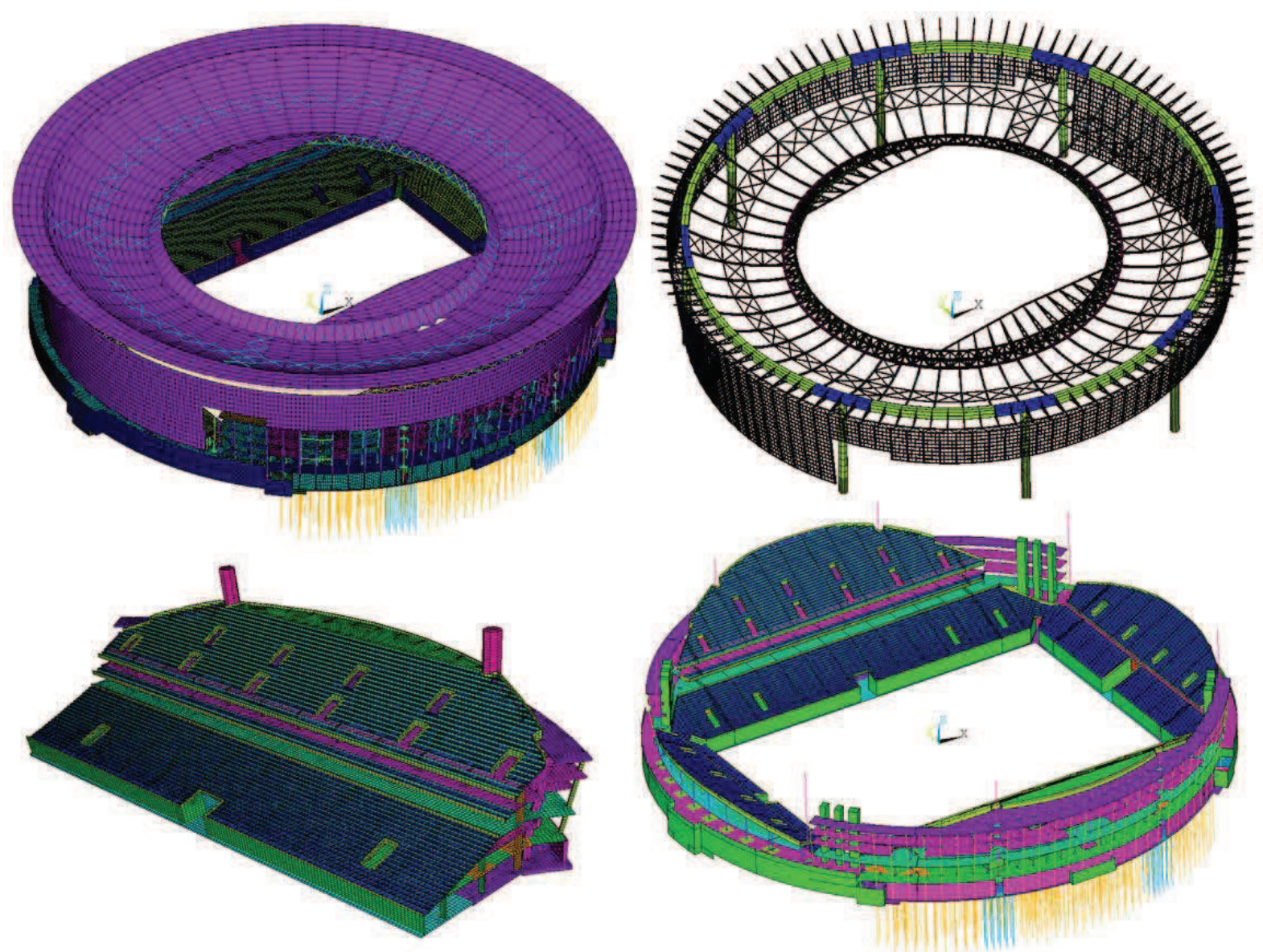

Figure 19. Analysis of stress-strain state, strength and stability of load-bearing structures of football stadiums of the World Cup 2018 (ANSYS). Samples.

2. Complex, including record-sized (up to 200 million unknowns) three-dimensional stationary and non-stationary problems of building aerodynamics dealing with computing of average and pulsating components of wind loads, wind loads on facade and enclosing structures, pedestrian comfort of numerous unique objects:

- high-rise buildings, structures and complexes (Moscow International Business Center "Moscow-City", "Gazoil City" (Moscow), "Zodiac" (Moscow), "Sky Fort" (Moscow), "Dirigible" (Moscow), "Rublevsky Lights" (Moscow), "Aquamarine" (Vladivostok), group of buildings of National Research Moscow State University of Civil Engineering, Ostankino TV Tower in Moscow, buildings located at Saint-Petersburg, Kiev, Astana, etc.);
- large-span buildings and structures (stadiums "Moskvich" (Moscow), "Zenit" (Saint-Petersburg), railway station in Adler, a ski jumping complex of Winter Olympic Games - 2014, etc.);

- monuments (monument on Poklonnaya Hill (Moscow), monuments "Conquerors of the Cosmos" and "Worker and Collective Farm Girl" at the Exhibition of Economic Achievements (VDNKh, Moscow), etc.);

- complex of basic structures of nuclear power plant with WWER (reactor compartments, engine rooms, evaporative cooling towers, etc.) with allowance for extreme (hurricane) wind and tornado.

Besides, contemporary problems of refined numerical modelling and aircraft crashes are considered for the basic structures of nuclear power plants of various types (WWER, RBMK and BN). 


\begin{tabular}{|c|c|c|c|c|c|c|}
\hline No. & $\begin{array}{l}\text { Finite element models } \\
\text { of system/ subsystem }\end{array}$ & Visualization & 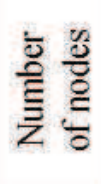 & 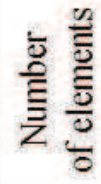 & $\begin{array}{l}\text { Types } \\
\text { of finite } \\
\text { elements }\end{array}$ & 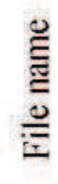 \\
\hline 1 & $\begin{array}{l}\text { "foundation - reinforced } \\
\text { concrete structures } \\
\text { of stadium bowl" }\end{array}$ & & $\frac{1}{2}$ & $\begin{array}{l}\text { ฟे } \\
\text { సิ }\end{array}$ & $\begin{array}{c}\text { SHELL181 } \\
\text { BEAM188 } \\
\text { MPC184 } \\
\text { SURF154 } \\
\text { COMBIN14 }\end{array}$ & $\frac{8}{\frac{8}{8}}$ \\
\hline 2 & "steel structures of roof" & & $\begin{array}{l}\text { है } \\
\text { के }\end{array}$ & $\frac{\text { है }}{\bar{v}}$ & $\begin{array}{c}\text { BEAM188 } \\
\text { MPC184 } \\
\text { SURF154 } \\
\text { COMBIN14 }\end{array}$ & $\frac{\text { s }}{5}$ \\
\hline 3 & $\begin{array}{l}\text { "foundation - reinforced } \\
\text { concrete structures } \\
\text { of stadium bowl - } \\
\text { steel structures of roof" }\end{array}$ & & 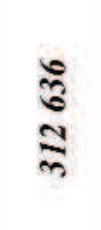 & 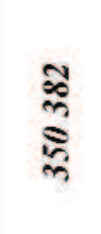 & $\begin{array}{c}\text { SHELL181 } \\
\text { BEAM188 } \\
\text { MPC184 } \\
\text { SURF154 } \\
\text { COMBIN14 }\end{array}$ & 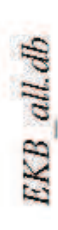 \\
\hline
\end{tabular}

Figure 20. Analysis of stress-strain state, strength and stability of load-bearing structures of football stadiums of the World Cup 2018 (ANSYS). Samples.

\section{ACKNOWLEDGMENT}

The Reported study was Funded by Government Program of the Russian Federation "Development of science and technology" (2013-2020) within Program of Fundamental Researches of Ministry of Construction, Housing and Utilities of the Russian Federation and Russian Academy of Architecture and Construction Sciences, the Research Project 7.1.1".

\section{REFERENCES}

1. Akimov P.A. Correct Discrete-Continual Finite Element Method of Structural Analysis Based on Precise Analytical Solutions of Resulting Multipoint Boundary Problems for Systems of Ordinary Differential Equations. // Applied Mechanics and Materials Vols. 204-208 (2012), pp. 4502-4505.

2. Akimov P.A., Aslami M., Mozgaleva M.L., Mskhalaya Z.I. Semianalytical Analysis of Shear Walls with the Use of DiscreteContinual Finite Element Method. Part 1: Mathematical Foundations. // MATEC Web Conferences, Vol. 86 (2016) 8 pages. 
Alexander M. Belostotsky, Pavel A. Akimov, Irina N. Afanasyeva, Taymuraz B. Kaytukov

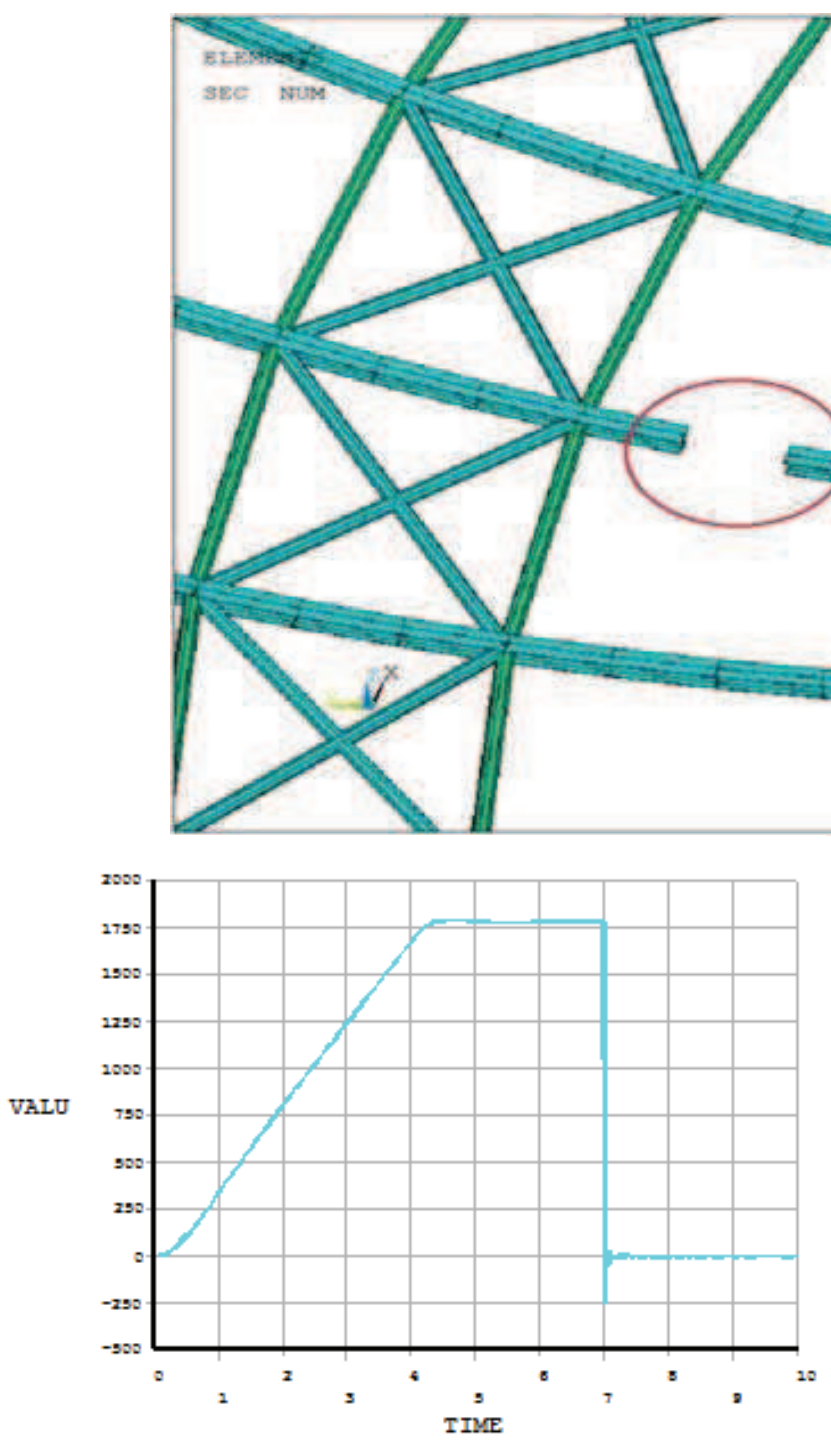

Change in longitudinal force in the damaged suspension, $k N$

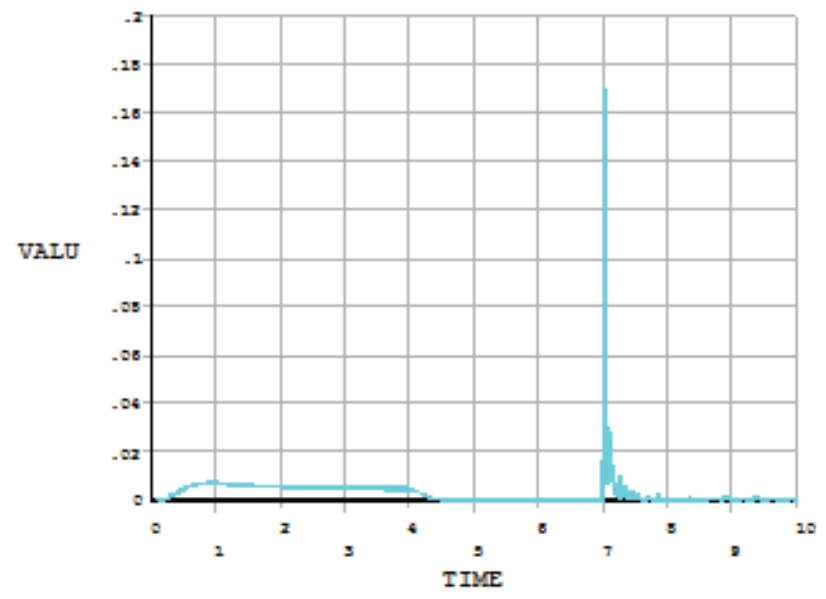

The kinetic energy at the site In the area of the removed element, $\mathrm{kJ}$

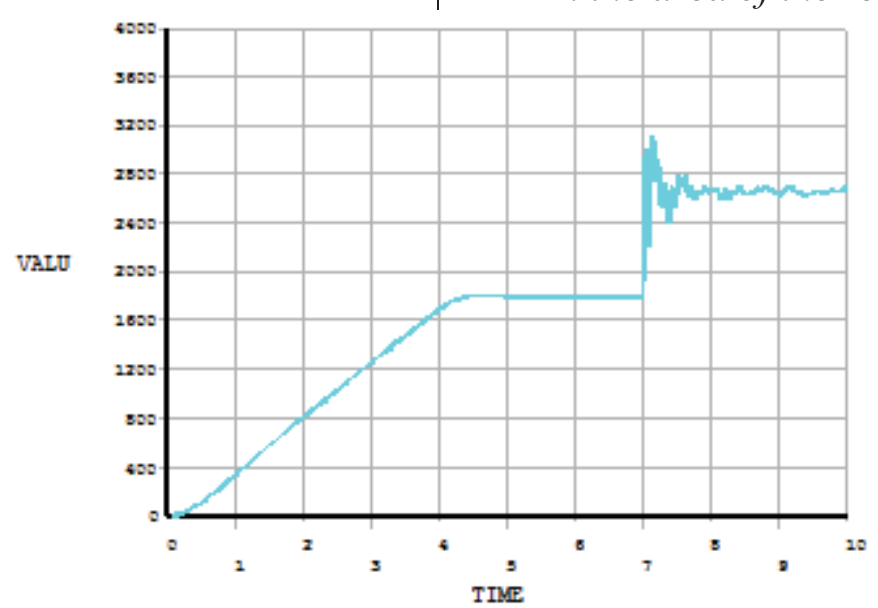

Change in longitudinal force in the adjacent suspension, $k N$

Figure 21. Analysis of stress-strain state, strength and stability of load-bearing structures of football stadiums of the World Cup 2018 (ANSYS). Samples. 
3. Akimov P.A., Aslami M., Mozgaleva M.L. Semianalytical Analysis of Shear Walls with the Use of Discrete-Continual Finite Element Method. Part 2: Numerical Examples, Future Development. // MATEC Web Conferences, Vol. 86 (2016) 8 pages.

4. Akimov P.A., Belostotskiy A.M., Mozgaleva M.L., Mojtaba Aslami, Negrozov O.A. Correct Multilevel DiscreteContinual Finite Element Method of Structural Analysis. // Advanced Materials Research Vol. 1040 (2014), pp. 664-669.

5. Akimov P.A., Mozgaleva M.L. Method of Extended Domain and General Principles of Mesh Approximation for Boundary Problems of Structural Analysis. // Applied Mechanics and Materials, Vols. 580583 (2014), pp. 2898-2902.

6. Akimov P.A., Mozgaleva M.L., Mojtaba Aslami, Negrozov O.A. About Verification of Discrete-Continual Finite Element Method of Structural Analysis. Part 1: Two-Dimensional Problems // Procedia Engineering, Vol. 91 (2014), pp. 2-7.

7. Akimov P.A., Mozgaleva M.L., Negrozov O.A. About Verification of DiscreteContinual Finite Element Method for TwoDimensional Problems of Structural Analysis. Part 1: Deep Beam with Constant Physical and Geometrical Parameters Along Basic Direction. // Advanced Materials Research, Vols. 1025-1026 (2014), pp. 89-94.

8. Akimov P.A., Mozgaleva M.L., Negrozov O.A. About Verification of DiscreteContinual Finite Element Method for Two-Dimensional Problems of Structural Analysis. Part 2: Deep Beam with Piecewise Constant Physical and Geometrical Parameters Along Basic Direction. // Advanced Materials Research, Vols. 10251026 (2014), pp. 95-103.

9. Akimov P.A., Mozgaleva M.L., Sidorov V.N. About Verification of DiscreteContinual Finite Element Method of Structural Analysis. Part 2: ThreeDimensional Problems // Procedia Engineering, Vol. 91 (2014), pp.14-19.
10. Akimov P.A., Negrozov O.A. Semianalytical Structural Analysis Based on Combined Application of Finite Element Method and Discrete-continual Finite Element Method Part 1: Two-Dimensional Theory of Elasticity. // Procedia Engineering, Vol. 153 (2016) pp. 8-15.

11. Alawadhi E.M. Finite Element Simulations Using ANSYS, CRC Press, 2009, 416 p.

12. Barbero E.J. Finite Element Analysis of Composite Materials Using ANSYS, CRC Press, 2013, 366 p.

13. Belostosky A.M., Akimov P.A. Adaptive Finite Element Models Coupled with Structural Health Monitoring Systems for Unique Buildings. // Procedia Engineering, Vol. 153 (2016) pp. 83-88.

14. Belostosky A.M., Akimov P.A., Afanasyeva I.N. Multilevel Methodology of Numerical Seismic Analysis of Coupled Systems "Foundation - Shell - Pontoon (Floating Roof) -Column(s) - Fluid". // Procedia Engineering, Vol. 153 (2016) pp. 89-94.

15. Belostosky A.M., Akimov P.A., Kaytukov T.B., Petryashev N.O., Petryashev S.O., Negrozov O.A. Strength and Stability Analysis of Load-bearing Structures of Evolution Tower with Allowance for Actual Positions of Reinforced Concrete Structural Members. // Procedia Engineering, Vol. 153 (2016) pp. 95-102.

16. Belostosky A.M., Penkovoy S.B., Scherbina S.V., Akimov P.A., Kaytukov T.B. Correct Numerical Methods of Analysis of Structural Strength and Stability of HighRise Panel Buildings - Part 1: Theoretical Foundations of Modelling, Key Engineering Materials, Vol. 685 (2016) pp. 217-220.

17. Belostosky A.M., Penkovoy S.B., Scherbina S.V., Akimov P.A., Kaytukov T.B. Correct Numerical Methods of Analysis of Structural Strength and Stability of High-Rise Panel Buildings - Part 2: Results of Modelling. // Key Engineering Materials, Vol. 685 (2016) pp. 221-224.

18. Dill E.H. The Finite Element Method for Mechanics of Solids with ANSYS Applitions, CRC Press, 2011, 508 p. 
19. Hanson R.J., Hopkins T. Numerical Computing With Modern Fortran (Applied Mathematics), SIAM-Society for Industrial and Applied Mathematics, 2013, 260 p.

20. Lee H.H. Finite Element Simulations with ANSYS Workbench 16, SDC Publications, 2015, $610 \mathrm{p}$.

21. Madenci E., Guven I. The Finite Element Method and Applications in Engineering Using ANSYS, Springer, 2015, 657 p.

22. Moaveni S. Finite Element Analysis: Theory and Application with ANSYS, Prentice Hall, 2014, 936 p.

23. Negrozov O.A., Akimov P.A., Lantsova I.Yu. Semianalytical Structural Analysis Based on Combined Application of Finite Element Method and Discrete-continual Finite Element Method Part 4: Verification Samples. // Procedia Engineering, Vol. 153 (2016) pp. 926-932.

24. Zienkiewicz O.C., Morgan K. Finite Elements and Approximation. Dover Publications, 2006, $352 \mathrm{p}$.

25. Zienkiewicz O.C., Taylor R.L. The Finite Element Method for Solid and Structural Mechanics. Volume 2. ButterworthHeinemann, 2005, 736 p.

26. Zienkiewicz O.C., Taylor R.L., Zhu J.Z. The Finite Element Method: Its Basis and Fundamentals. Butterworth-Heinemann, 2005, $752 \mathrm{p}$.

\footnotetext{
Alexander M. Belostotsky, Corresponding Member of Russian Academy of Architecture and Construction Sciences, $\mathrm{PhD}$, Professor, StaDyO Research \& Engineering Center; Deputy Director of Research \& Education Center of Computation Simulation, National Research Moscow State University of Civil Engineering, 26, Yaroslavskoe Shosse, Moscow, 129337, Russia; phone/fax: +7 (499) 929-50-17; e-mail: stadyo@stadyo.ru,niccm@mgsu.ru

Pavel A. Akimov, Full Member of the Russian Academy of Architecture and Construction Sciences, PhD, Professor, Chief Scientific Secretary of Russian Academy of Architecture and Construction Sciences; StaDyO Research \& Engineering Center; Department of Applied Mathematics, Moscow State University of Civil Engineering; 24, Ul. Bolshaya Dmitrovka, 107031, Moscow, Russia; phone +7(495) 625-71-63; fax: +7 (495) 650-27-31;

E-mail: akimov@raasn.ru, pavel.akimov@gmail.com.
}

Irina N Afanasyeva, Ph.D., Applied Mathematics and Computer Sciences; Director of Research \& Education Center of Computation Simulation; National Research Moscow State University of Civil Engineering; 26, YaroslavskoeShosse, 129337, Moscow, Russia; tel./fax: +7 (499)183-59-94; e-mail: niccm@mgsu.ru

Taymuraz B. Kaytukov, Advisor of Russian Academy of Architecture and Construction Sciences, PhD, Associate Professor, Department of Applied Mathematics, National Research Moscow State University of Civil Engineering; Vice Executive Scientific Secretary of Russian Academy of Architecture and Construction Sciences; 26, Yaroslavskoe Shosse, Moscow, 129337, Russia, phone/fax: +7(499) 183-59-94, e-mail: tkaytukov@gmail.com.

Белостоцкий Александр Михайлович, членкорреспондент РААСН, доктор технических наук, профессор, генеральный директор ЗАО «Научноисследовательский центр СтаДиО», профессор кафедры прикладной математики Национального исследовательского Московского государственного строительного университета (НИУ МГСУ), заместитель директора научно-образовательного центра компьютерного моделирования уникальных зданий, сооружений и комплексов НИУ МГСУ; 125040, Россия, г. Москва ул. 3-я Ямского Поля, д.18, 8 этаж, офис 810, тел. +7 (495) 706-88-10, e-mail: stadyo@stadyo.ru.

Акимов Павел Алексеевич, академик РАACH, профессор, доктор технических наук; Главный ученый секретарь РАACH; заместитель генерального директора по науке $3 \mathrm{AO}$ «Научно-исследовательский центр СтаДиО», профессор кафедры прикладной математики Национального исследовательского Московского государственного строительного университета (НИУ МГСУ); 107031, г. Москва, ул. Большая Дмитровка, д. 24, стр. 1; тел. +7(495) 625-71-63; факс +7 (495) 65027-31; e-mail: akimov@raasn.ru, pavel.akimov@gmail.com.

Афанасьева Ирина Николаевна, кандидат технических наук, старший преподаватель кафедры прикладной математики, директор Научно-образовательного центра компьютерного моделирования уникальных зданий, сооружений и комплексов; Национальный исследовательский университет Московский государственный строительный университет; 129337, Россия, г. Москва, Ярославское шоссе, дом 26; тел./факс: +7 (499)183-59-94; e-mail: niccm@mgsu.ru

Кайтуков Таймураз Батразович, советник РААСН, кандидат технических наук, доцент, доцент кафедры прикладной математики Национального исследовательского Московского государственного строительного университета, заместитель главного ученого секретаря Российской академии архитектуры и строительных наук; Россия, 129337, г. Москва, Ярославское шоссе, д. 26; тел/факс: +7 (499) 183-59-94;

e-mail: tkaytukov@gmail.com. 